\title{
11. MIDDLE EOCENE THROUGH QUATERNARY PLANKTONIC FORAMINIFERS FROM THE SOUTHERN ANGOLA BASIN: DEEP SEA DRILLING PROJECT LEG 731
}

\author{
R. Z. Poore, U.S. Geological Survey, Reston, Virginia
}

\begin{abstract}
Middle Eocene through Quaternary sediments were recovered from the southern Angola Basin at Sites 519 to 523 during Leg 73 of the Deep Sea Drilling Project. Clearly defined magnetostratigraphic records and relatively well preserved faunas occur in the lower Pliocene sediments of Hole 519, upper Eocene to Oligocene sediments of Hole 522, and middle Eocene sediments of Hole 523 . The apparently complete Oligocene sequence in Hole 522 is especially important for establishing a direct calibration of calcareous plankton biostratigraphy and magnetostratigraphy in a midlatitude deep sea section.

The Miocene assemblages in Holes 520 and 521 demonstrate that Sphaeroidinellopsis subdehiscens, Globigerina druryi, and forms very similar to $G$. nepenthes range down to, and perhaps below, the base of the middle Miocene. Thus, the standard middle Miocene zonation of Blow (1969), which uses the successive first appearances of Sphaeroidinellopsis subdehiscens and Globigerina nepenthes to define Zone N13, requires revision.

A new midlatitude Oligocene zonation (OL1 to OL6) developed primarily from the faunal sequence of Hole 522 is proposed and correlated to standard zonations developed in tropical and other extra-tropical regions.
\end{abstract}

\section{INTRODUCTION}

Eocene through Quaternary sediments were recovered from the southern Angola Basin at Sites 519 to 523 during Leg 73 of the Deep Sea Drilling Project. The sites are located on progressively older crust on the east side of the Mid-Atlantic Ridge (Fig. 1, Table 1). Sites 519 to 521 , a three-site traverse at $\approx 26^{\circ} \mathrm{S}$, were drilled to study Miocene paleoceanography and the spreading history of the South Atlantic. Sites 522 and 523 were drilled farther east to obtain high-carbonate Paleogene sections. The hydraulic piston corer (HPC) was used, with varying degrees of success, at all sites. The hydraulic piston cores from portions of most sites were good enough for paleomagnetic determinations, but many other cores were unsuitable for paleomagnetic analysis because of poor recovery, core disturbance, and extreme sediment condensation.

One of the primary objectives of this investigation was to document the distribution of stratigraphically diagnostic planktonic foraminifers in Tertiary sediments with paleomagnetic control. Thus, Quaternary sediments, Tertiary sediments with mixed or badly dissolved faunas, and intervals with ambiguous magnetic signatures were not studied in detail. The correlation of the paleomagnetic and biostratigraphic results for Leg 73 is summarized in Poore et al. (this vol.).

Estimates of the abundance of planktonic foraminifer taxa in samples examined for this report are provided in Figures 2 to 6 . The estimates were made by examining a more or less uniform amount of processed material ( $\geq 149 \mu \mathrm{m}$ size fraction) strewn over a standard 60-square micropaleontologic slide. Taxa that occurred several times per square were tabulated as abundant, those that

\footnotetext{
${ }^{1}$ Hsü, K. J., LaBrecque, J. L., et al., Init. Repts. DSDP, 73: Washington (U.S. Govt. Printing Office).
}

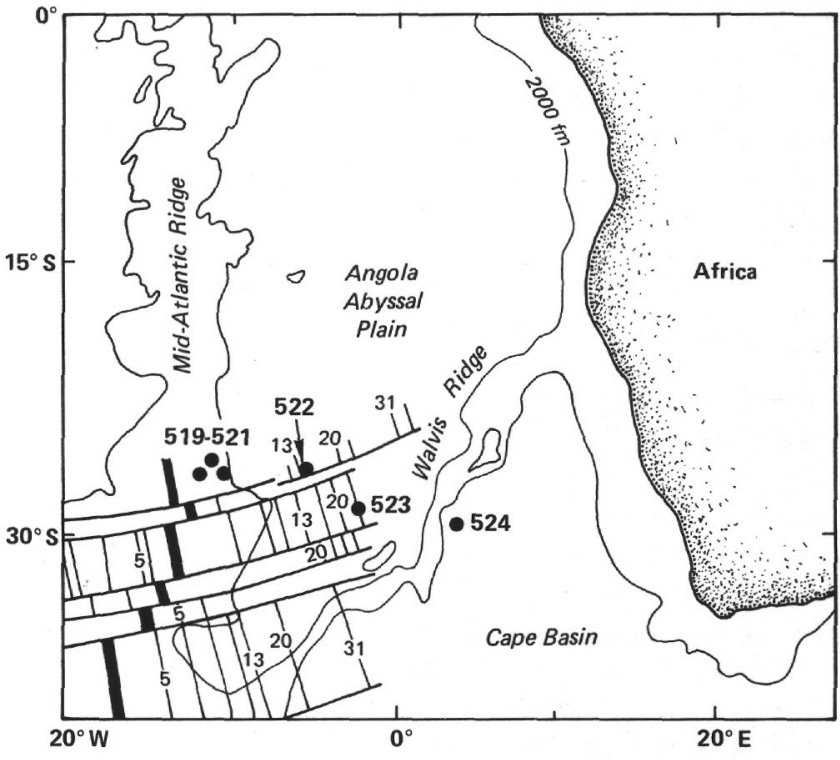

Figure 1. Location of Leg 73 sites. Smaller numbers refer to magnetic anomalies.

occurred about once per square were tabulated as common, and those that occurred about once per several squares were tabulated as few. Taxa that required a more extensive search or were encountered only in the $<149 \mu \mathrm{m}$ size fraction were tabulated as sparse. These qualitative data are intended primarily to help interested researchers select samples for further study.

No single standard foraminifer zonation was found to be suitable for the faunas recovered during Leg 73 . For the Paleogene sediments of Sites 522 and 523 the zonation of Stainforth et al. (1975) was used, supplemented by the middle Eocene zonation of Toumarkine and Bolli (1970) and an Oligocene zonation defined in 
Table 1. Locations and corrected water depths of Sites 519 to 523 .

\begin{tabular}{cccc}
\hline Site & $\begin{array}{c}\text { Latitude } \\
(\mathrm{S})\end{array}$ & $\begin{array}{c}\text { Longitude } \\
(\mathrm{W})\end{array}$ & $\begin{array}{c}\text { Water } \\
\text { depth } \\
(\mathrm{m})\end{array}$ \\
\hline 519 & $26^{\circ} 08.2^{\prime}$ & $11^{\circ} 39.97^{\prime}$ & 3769 \\
520 & $25^{\circ} 31.40^{\prime}$ & $11^{\circ} 11.14^{\prime}$ & 4207 \\
521 & $26^{\circ} 04.43^{\prime}$ & $10^{\circ} 15.87^{\prime}$ & 4125 \\
522 & $26^{\circ} 06.83^{\prime}$ & $5^{\circ} 07.78^{\prime}$ & 4441 \\
523 & $28^{\circ} 33.13^{\prime}$ & $2^{\circ} 15.08^{\prime}$ & 4573 \\
\hline
\end{tabular}

this report. For Hole 519, the zonation of Berggren (1973, 1977) was useful for the Pliocene assemblages, and the standard zonation of Blow (1969) was generally useful for the Miocene and Quaternary assemblages. However, several major problems with the Miocene zonation of Blow (1969) were found in the middle Miocene sediments of Holes 520 and 521 .

In this chapter a presentation of data from Sites 519 to 523 is followed by a discussion of the anomalous ranges of key middle Miocene taxa in Holes 520 and 521. The environmental implications of the diverse Oligocene assemblages in Hole 522 are discussed, and an alternative Oligocene zonation is defined. Comments on informally recognized and other selected taxa are presented in Appendix A, and a list of species identified during this study is presented in Appendix B. Abbreviated sample designations follow standard DSDP convention.

\section{SITE SUMMARIES}

\section{Site 519}

Site 519 is between Anomalies 5 and $5 \mathrm{~A}$ in a sediment pond on the slope of a local ridge. Two holes (519 and 519A) were cored at Site 519. Hole 519 was continuously cored with the HPC until basement was encountered at about $151 \mathrm{~m}$ sub-bottom. Several discontinuous sediment cores and two basement cores were recovered by rotary coring in Hole 519A; no samples from Hole 519A were examined for this report.

Planktonic foraminifers are generally abundant and well preserved in the upper $104 \mathrm{~m}$ (Cores 1-25) of Hole 519. Assemblages that show marked signs of dissolution occur, however, in Samples 519-14,CC, 519-19,CC, and 519-21,CC. All samples below Core 25 show signs of strong dissolution. The occurrences and abundance of the taxa found in Hole 519 are shown in Figure 2.

Cores 1 through 4 contain rich Quaternary low-latitude assemblages. The taxa that occur in this interval include Globorotalia truncatulinoides, G. tumida, Globigerinoides sacculifer, G. ruber, G. conglobatus, and Orbulina universa. Cores 5 to 9 contain mixed Pliocene and Quaternary assemblages; the Pliocene component is dominant. Globorotalia truncatulinoides occurs with Sphaeroidinellopsis spp. and Globoquadrina altispira in Samples 519-5,CC and 519-9,CC. Sample 519-8,CC could be Pliocene or Quaternary, and Samples 519-10,CC through 519-15,CC appear to be late Pliocene.
Sedimentological and paleontological evidence (see site chapter and Poore et al., this vol.) show that a combination of slumping and downhole contamination above Core 15 has mixed the Quaternary and Pliocene sediments. Thus, the zonation of Cores 5 through 15 is difficult. The placement of the Pliocene/Pleistocene boundary between Cores 5 and 4 is based primarily on coccolith and paleomagnetic data.

The interpretation of the lower portion of Hole 519 is complicated by pervasive downhole contamination, reworking, and increased dissolution. For example, Globorotalia truncatulinoides and $G$. inflata occur sporadically in core-catcher samples down to the base of the section. Downhole contamination was noted in many core-catcher samples from all Leg 73 holes; thus, corecatcher occurrences cannot be relied upon to establish the lower stratigraphic limits of taxa. Paleomagnetic data from Hole 519 show that the base of the Gilbert occurs between Sections 1 and 2 of Core 28 and that the Gilbert/Gauss boundary occurs in Core 18 . These levels are used to recognize the Miocene/Pliocene boundary and the early/late Pliocene boundary, respectively.There is an offset in Figure 2 between this Miocene/Pliocene boundary and the base of "Pliocene" Zone PL1 (Berggren, 1973, 1977) as recognized by the last occurrence of Globoquadrina dehiscens in Sample 519-29-3, 30-32 cm (occurrences of $G$. dehiscens in Samples 519-27,CC and 519-7, CC are considered reworked).

The last consistent occurrence of Globigerina nepenthes in Sample 519-21,CC and the last occurrence of Globorotalia margaritae in Sample 519-20,CC are used to establish the upper limits of Zones PL2 and PL3, respectively. The sparse occurrences of Globigerina nepenthes in Samples 519-19,CC and 519-18,CC are interpreted as reworking. As calibrated by magnetics, the last occurrences of Globoquadrina dehiscens and Globorotalia margaritae in the Hole 519 assemblages represent local events that are older than their last appearance datum events (Poore et al., this vol.).

The basement age as determined by magnetics (younger than Anomaly 5A), in conjunction with the occurrence of Globoquadrina dehiscens, indicates that the strongly dissolved foraminifer assemblages from the lower portion of the sedimentary column of Hole 519 are referable to upper Miocene Zones N16 or N17.

\section{Site 520}

Site 520 is located on the western edge of Anomaly $5 \mathrm{~B}$ near the axis of a deep narrow basin. Two holes were drilled at Site 520. The entire 450-m sedimentary section was discontinuously cored, and one basement core was cut by rotary coring in Hole 520 . Recovery was poor, and most sediment cores were highly disturbed. Hole 520A was an unsuccessful attempt to use the HPC to sample the upper part of the sedimentary section; only one highly disturbed core was recovered from Hole 520A.

Planktonic foraminifers are poorly represented in the sediments recovered in Hole 520. The foraminifer assemblages in almost all the samples examined show evi- 
dence of moderate to intense dissolution. A trace of Quaternary sediment was recovered in Core 1, and a collapsed core liner caused problems with Core 2, so these cores were not examined for foraminifers. A relatively well preserved upper Pliocene foraminifer assemblage occurs in Sample 520-3-7, 5-7 cm. The taxa present include Globigerinoides ruber, G. obliquus, G. extremus, G. conglobatus, Globorotalia crassaformis, and G. inflata.

Cores 4 through 10 yield sparse, poorly preserved assemblages. The occurrence of Globorotalia puncticulata in Sample 520-5,CC supports the assignment (based on calcareous nannofossils) of this interval to the lower Pliocene. A few specimens of $G$. crassaformis in Sample 520-9, CC also indicate a Pliocene assignment; the nannofossils in Sample 520-9, CC, however, suggest an upper Miocene assignment (Percival, this vol.).

Samples from Cores 11 through 17 contain extremely poor, strongly dissolved assemblages or are barren of planktonic foraminifers. Planktonic foraminifers are more common and better preserved in Cores 18 through 25 . These cores are from an interval that consists mostly of slump deposits that are intercalated with minor amounts of in situ sediments. Taxa that are common throughout this interval include Sphaeroidinellopsis subdehiscens, S. seminulina, Globigerina nepenthes, Globoquadrina dehiscens, G. altispira, and Globorotalia conoidea (s.1.). Planktonic foraminifers are essentially absent from Cores 26 and 27, although the slump deposits occur down into Core 29. Sample 520-28,CC is contaminated with Quaternary through lower Pliocene species. The interval from Core 11 to Core 28 is assigned to the upper Miocene Nannofossil Zone NN11 (Percival, this vol.).

The lowest slump deposit in Section 1 of Core 29 overlies brown clays that contain highly dissolved middle Miocene assemblages (Fig. 3). The assemblages, which include Sphaeroidinellopsis subdehiscens, Globigerina druryi, and sporadic and questionable representatives of $G$. nepenthes, suggest assignment to middle Miocene Zones N13-N14. The calcareous nannofossils from Core 29, however, suggest a somewhat older age assignment (Percival, this vol.), and I have tentatively assigned Core 29 to the zonal interval N9-N12.

The Hole 520 data and the observations made in Hole 521 (see following section) reveal that the lower limits of several taxa used as primary or secondary criteria for the middle Miocene zones of Blow (1969) require revision.

\section{Site 521}

Site 521 is located on Anomaly $5 \mathrm{C}$ in a region of pelagic drape sediments. Two holes were continuously cored to basement with the HPC at this site. Hole 521A was offset about $800 \mathrm{~m}$ from the Hole 521 . Only samples from Hole 521 were examined for this report.

Planktonic foraminifers are abundant and well preserved in Cores 1 through 10 of Hole 521. In Section 1 of Core 11 the preservation and abundance of planktonic foraminifers declines markedly because of increased dissolution. Assemblages consisting of dissolu- tion-resistant taxa, such as Globoquadrina dehiscens, Globigerina nepenthes, and Globorotalia conoidea, are present along with abundant foraminifer fragments from the bottom of Core 11 through Core 16. The preservation of planktonic foraminifers begins to improve in Core 13 and continues to improve downsection to the sediment/basalt contact in Core 21 .

The Pliocene/Pleistocene boundary is placed between Samples 521-3,CC and 521-4,CC because of the first (lowest) occurrence of G. truncatulinoides in Sample $521-3$, CC. Samples 521-4,CC through 521-10,CC contain relatively diverse Pliocene assemblages. Cores 4 through 6 are post-Sphaeroidinellopsis extinction. Sample 521-11,CC yields a highly dissolved assemblage with primitive forms of $G$. crassaformis and rare Globigerinoides conglobatus. Sample 521-11,CC is tentatively assigned to Zone PL1.

A meager assemblage from Sample 521-12,CC is not age diagnostic, but the occurrence of Globoquadrina dehiscens in Sample 521-13,CC indicates a late Miocene (N17) or older assignment. Planktonic foraminifer assemblages from Cores 14 through 16 are only diagnostic of middle to upper Miocene.

Figure 4 shows the range and abundance of foraminifers in Cores 17 through 21. Note that Sphaeroidinellopsis subdehiscens, Globigerina druryi, and forms similar to $G$. nepenthes occur with assemblages that contain, for example, Globigerinoides sicanus and Praeorbulina spp. and are clearly referable to Zones N8 and N9. The consistent occurrence of these "younger" taxa throughout the cores and the lack of Pliocene or Pleistocene taxa indicate that the foraminifer assemblages from Cores 17 through 21 are in situ and have not been altered by downhole contamination. The nannofossil assemblages from this interval are indicative of Zones NN4 and NN5 (Percival, this vol.) and corroborate the assignment of these cores to basal middle Miocene. Moreover, the nannofossil assemblages show no signs of downhole contamination. Thus, the Hole 521 occurrences establish that $S$. subdehiscens and forms very similar to Globigerina nepenthes range well down into the middle Miocene. The implications of these observations are discussed in a later section.

\section{Site $\mathbf{5 2 2}$}

Site 522 is located over Anomaly 16 on a small plateau covered with pelagic drape sediments. Three holes were cored at Site 522 . Hole 522 was continuously cored with the HPC almost to basement. A second HPC hole (Hole 522A) was then cored to basement without changing the position of the ship. Hole 522B was drilled with rotary techniques after the ship was offset $100 \mathrm{ft}$. from Holes 522 and 522A, and samples of basalt basement were obtained. Samples from Hole 522 and the lowest six cores of Hole 522A were examined for this report.

\section{Hole 522}

Late Eocene through Quaternary planktonic foraminifers were recovered in Hole 522. Cores 1 through 3 contain diverse, moderately well preserved Quaternary assemblages. The Pliocene/Quaternary boundary is placed 


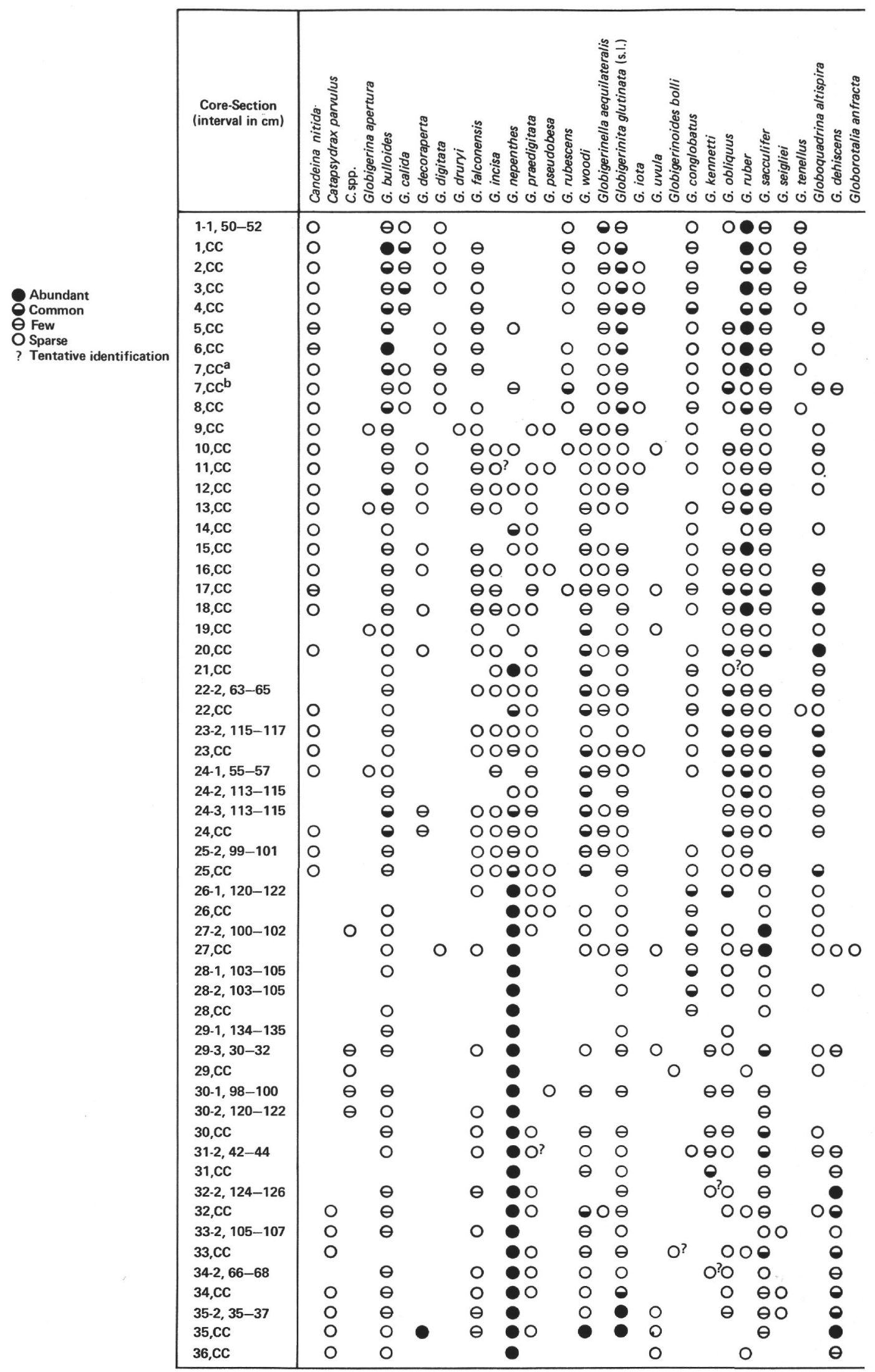

aLight sediment

bDark sediment

Figure 2. Planktonic foraminifers in samples from Hole 519. 


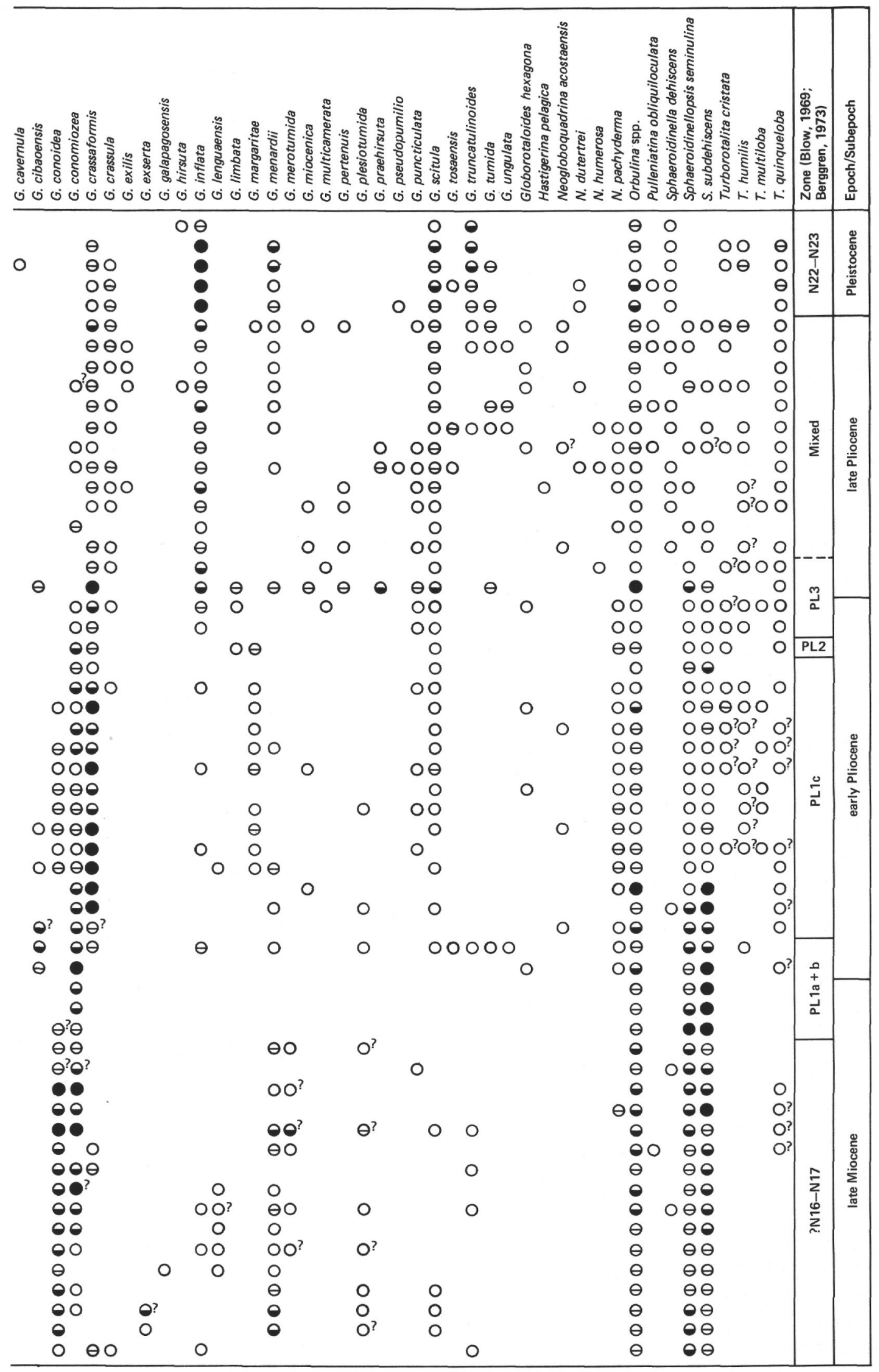

Figure 2. (Continued). 


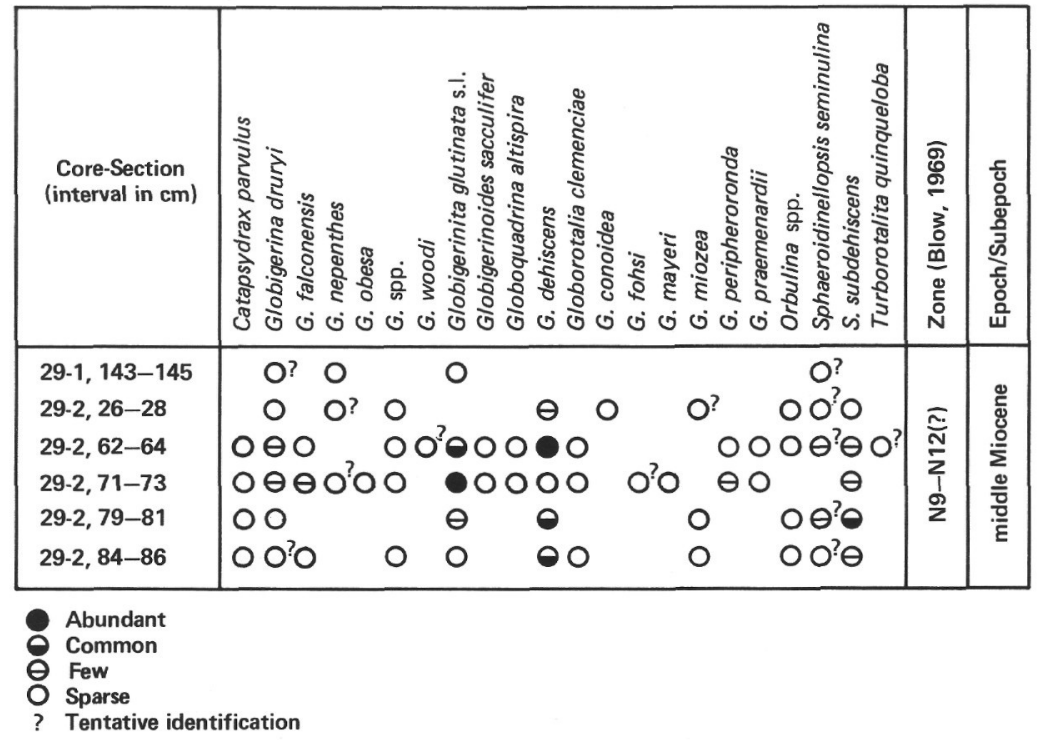

Figure 3. Planktonic foraminifers in Core 29 of Hole 520.

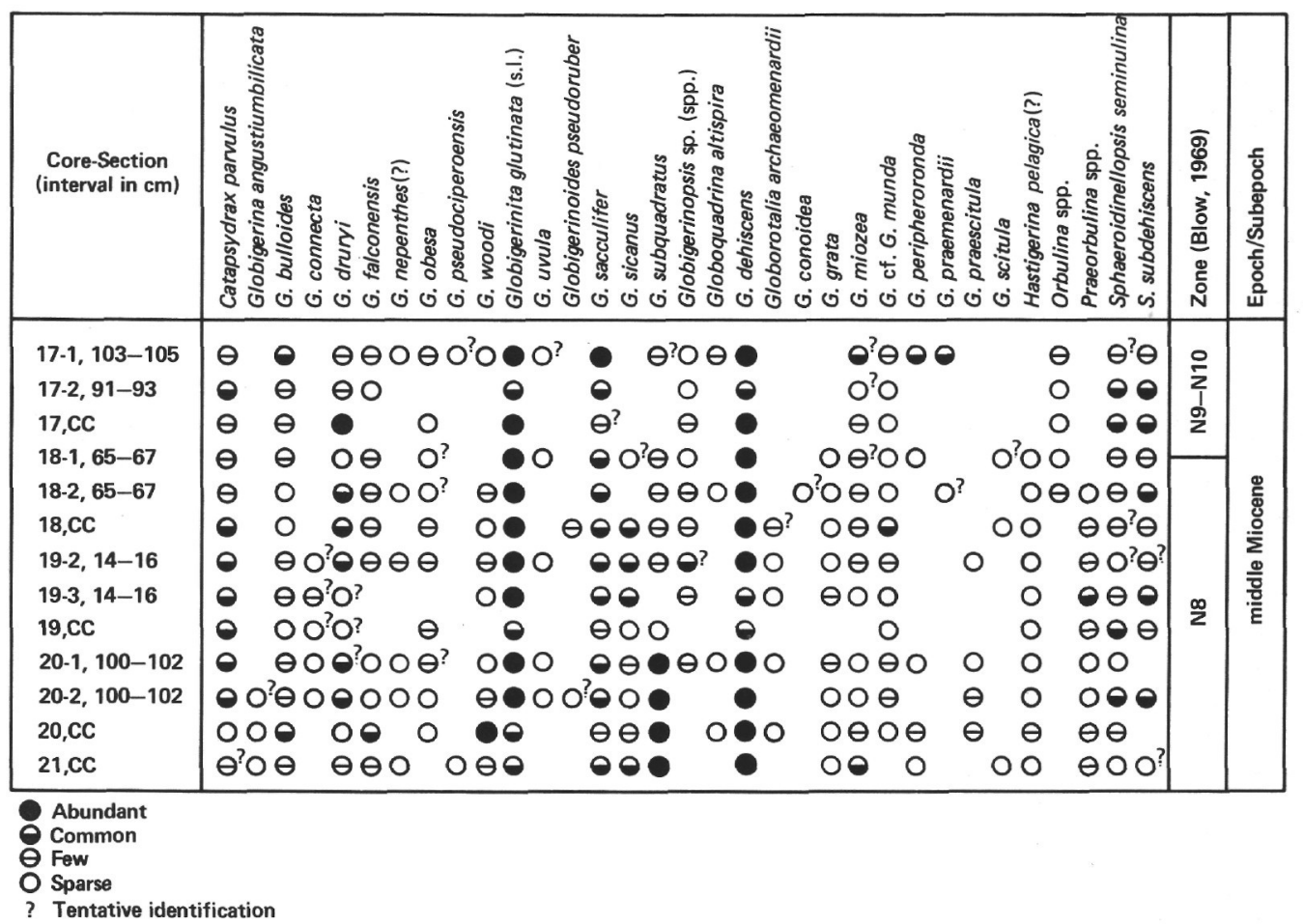

Figure 4. Planktonic foraminifers in Cores 17 through 21 of Hole 521.

between Samples 522-3, CC and 522-4,CC because of the lowest occurrence of Globorotalia truncatulinoides in Sample 522-3,CC.

Samples 522-4,CC through 522-8,CC are Pliocene. G. crassaformis, G. inflata or G. puncticulata, Orbulina universa, Globigerinoides obliquus, and G. conglobatus are consistent components of these Pliocene assemblages. Increasing intensity of dissolution from Core 4 to 8 is indicated by the increasing fragmentation of the foraminifer assemblages downsection. Samples 522-9,CC through $522-14, \mathrm{CC}$ are intensely dissolved, and the planktonic foraminifers in this interval are extremely sparse and poorly preserved. The few species identified from Samples 522-9,CC through 522-13,CC are not particularly age diagnostic.

The preservation of planktonic foraminifers begins to improve in Sample 522-15,CC. The range and abundance of taxa identified in samples from Cores 14 through 38 of Hole 522 are shown in Figure 5. Primary boundary indicators for the zonation of Stainforth et al. (1975) are present, but the placement of the exact limits of the Globigerina ampliapertura Zone is uncertain be- 
cause of the difficulty of deciding which specimens should be considered typical Globorotalia opima and the occurrence in Core 28 of isolated specimens of Pseudohastigerina.

The occurrence of Globigerinoides spp. in Sample 522-14,CC and of Globorotalia kugleri (s.1.) in Cores 14 through 17 suggests that the base of the G. kugleri Zone of Stainforth et al. (1975) and the Oligocene/Miocene boundary occur within Core 15 . Typical specimens of G. opima range from Sample 522-21,CC down through Core 26. Thus, Cores 15 through 20 are assigned to the Globigerina ciperoensis Zone and Cores 21 through 26 are assigned to the Globorotalia opima Zone.

The first consistent occurrence (downsection) of Pseudohastigerina in Sample 522-31,CC marks the top of the Cassigerinella chipolensis-Pseudohastigerina micra Zone. Cores 27 through 30 are thus assigned to the Globigerina ampliapertura Zone. Samples 522-31,CC through 522-35,CC contain a Pseudohastigerina sp. (or spp.), Chiloguembelina cubensis, and, usually, G. ampliapertura without Globorotalia cerroazulensis (s.1.) or Hantkenina. This interval is assigned to the Cassigerinella chipolensis-Pseudohastigerina micra Zone. The presence of Hantkenina and G. cerroazulensis in Core 36 marks the top of the Eocene. Note that Hantkenina extends one section above the last occurrence of $G$. cerroazulensis (s.l.). Although sparse, the Hantkenina in Sample 52236-1, 97-99 cm appear to be autochthonous, and I have used the last occurrence of Hantkenina to place the Eocene/Oligocene boundary between Cores 36 and 35 . Thus, there is a slight offset between the top of the $G$. cerroazulensis Zone and the Eocene/Oligocene boundary in Figure 5. Faunas from samples below Core 36 are also indicative of the $G$. cerroazulensis Zone.

The preservation of planktonic foraminifers in Cores 28 through 38 is fair to good. Changes in dissolution intensity are evident from sample to sample, however, suggesting that relatively short wavelength dissolution cycles occur in the late Eocene to early Oligocene.

\section{Hole 522A}

Samples were examined from the lowest six cores (Cores 26 through 31) of Hole 522A. Cores 26 through 28 duplicate the section recovered at the base of Hole 522. The faunas from Cores 30 and 31 of Hole 522A may be assigned to the Globorotalia cerroazulensis Zone, but the absence of Globigerina ampliapertura in the assemblages suggests that these cores are near the base of the Globorotalia cerroazulensis Zone.

An alternative zonation for the Oligocene, Zones OL1 to OL6, based on data from Site 522, is proposed in a later section.

\section{Site 523}

Site 523 is on Anomaly 21 in an area of pelagic drape sediments. Hole 523 was cored with the HPC until mechanical difficulties forced termination of the hole at a point estimated to be 5 to $20 \mathrm{~m}$ above basement. Core recovery was highly variable, and core disturbance was pronounced in the upper $73 \mathrm{~m}$ of the section (Cores 1-20). Core recovery improved and the degree of dis- turbance declined dramatically below Core 20 , probably because weather conditions improved. The section from 73 to $190 \mathrm{~m}$ sub-bottom (Cores 21-50) is almost continuous and yields a reliable magnetic polarity signal. The only significant gaps in the lower part of the section occur in Cores 29 and 31, where recovery was poor to zero, and a 5-m washed interval between Cores 47 and 48 that was made necessary by equipment failure.

Quaternary through middle Eocene planktonic foraminifers were recovered in Hole 523. In general, the middle Eocene, late Pliocene, and Quaternary assemblages are relatively diverse and moderately well preserved, whereas the late Eocene, Oligocene, Miocene, and early Pliocene assemblages are sparse and poorly preserved because of intense dissolution.

The Quaternary assemblages in Samples 523-1,CC and 523-2,CC contain abundant Globorotalia crassaformis, G. inflata, G. truncatulinoides, and Globigerina bulloides. Samples 523-3,CC through 523-6,CC yield similar assemblages but lack Globorotalia truncatulinoides. Samples 523-3,CC through 523-6,CC are thus assigned to the Pliocene, and the Pliocene/Quaternary boundary is placed between Samples 523-3,CC and 5232,CC.

Sample 523-7, CC contains sparse Pliocene microfossils, but the core is highly disturbed and the foraminifers present may be from downhole cavings. Samples 523$8, \mathrm{CC}$ through 523-10,CC contain fragments of planktonic foraminifers along with a few moderately well preserved Pliocene and Quaternary taxa such as $G$. tosaensis and $G$. inflata. Intact specimens of planktonic foraminifers in Samples 523-8,CC through 523-10,CC are clearly downhole contaminants.

Strongly dissolved assemblages occur in Sample 523$11, \mathrm{CC}$ through $523-16, \mathrm{CC}$. Only a few specimens of long-ranging early Miocene to Eocene taxa such as Catapsydrax dissimilis and Globorotaloides suteri were found in this interval. Calcareous nannofossils suggest that the Oligocene/Miocene boundary occurs between Samples 523-11,CC and 523-12,CC (Percival, this vol.).

A well preserved lower Oligocene assemblage occurs in Sample 523-17,CC, but strongly dissolved assemblages are present from Sample 523-18,CC through Sample 523-23,CC. Pliocene and Quaternary contaminants occur sporadically throughout this interval.

The preservation of foraminifers generally improves in samples from Cores 24 through 26, and the assemblages, which include Globigerina ampliapertura, $G$. euapertura, Globorotalia nana, G. gemma, and Pseudohastigerina spp., are considered Oligocene because of the associated Oligocene calcareous nannofossils. Sample 523-27,CC is barren of foraminifers, but Globigerinatheka spp., which are indicative of the Eocene, occur in Sample 523-28,CC. The Eocene/Oligocene boundary is interpreted as occurring between Samples 523-27,CC and $523-28, \mathrm{CC}$. The calcareous nannofossils indicate that the Eocene/Oligocene boundary is within or at the top of Core 28 (Percival, this vol.) and corroborate the interpretation of the foraminifer data.

The occurrences and abundance of taxa identified in Cores $\mathbf{2 8}$ through 50 are recorded in Figure 6. The assem- 


\begin{tabular}{|c|c|c|c|c|c|c|c|c|c|}
\hline $\begin{array}{c}\text { Core-Section } \\
\text { (interval in cm) }\end{array}$ & 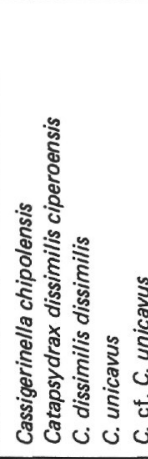 & 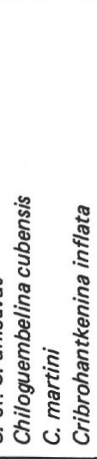 & 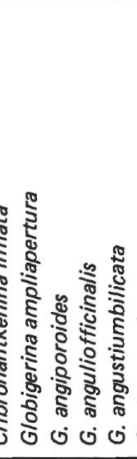 & 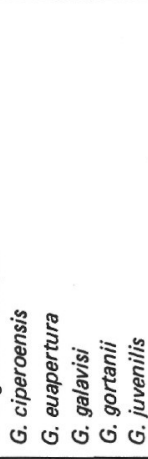 & है & 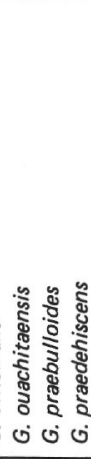 & 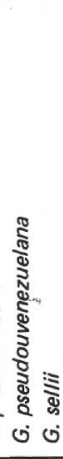 & 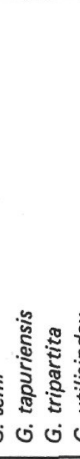 & 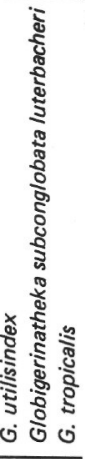 \\
\hline $14, \mathrm{CC}$ & 000 & & & $0 ?$ & & $\theta \theta$ & & & \\
\hline $15-2,54-56$ & $\theta \theta \theta$ & & & 0 ? & & 00 & & & \\
\hline $15, \mathrm{CC}$ & $\theta \theta \theta$ & & & $\theta$ ? & & 00 & & & \\
\hline $16-2,40-42$ & $\theta \theta$ & & 0 & $\theta$ & & $\theta \theta$ & & 0 & \\
\hline $16, \mathrm{CC}$ & $\theta \theta$ & & 0 & $\theta$ & & $\theta$ & & 0 & \\
\hline $17-2,105-107$ & 000 & & 0 & 00 & & 0 & & 0 & \\
\hline $17, \mathrm{CC}$ & 00 & & & 0 & & 0 & 0 & 0 & \\
\hline $18-2,10-12$ & $\theta$ & & & 0 & & & & & \\
\hline $18, \mathrm{CC}$ & 000 & & $\theta$ & $\theta$ & & & & $\theta$ & \\
\hline $19-2,30-32$ & 000 & & 0 & $\theta$ & & 0 & & $\theta$ & \\
\hline $19, \mathrm{Cc}$ & ০๑৩ & & & 0 & & 0 & 0 & $\theta$ & \\
\hline $20-1,110-112$ & $\theta \ominus \theta$ & & $\theta$ & $00 \theta$ & & & & 0 & \\
\hline $20, \mathrm{CC}$ & 000 & 0 & & $\theta \quad 0$ & & $\theta$ & & 0 & \\
\hline $21-2,119-121$ & $0 \theta \theta \theta$ & & 0 & $000 \theta$ & & 00 & & & \\
\hline $21, \mathrm{CC}$ & ०ө०० & & & 0000 & & 00 & & & \\
\hline $22-2,50-52$ & $00 \theta$ & & & 0 & & & & 0 & \\
\hline $23, \mathrm{CC}$ & O०० & 0 & $O \theta$ & $0 \theta \theta$ & & 0 & 0 & 0 & \\
\hline $24, \mathrm{CC}$ & Ө૭ & 0 & 0 & 0000 & & 0 & & & \\
\hline $25-2,33-35$ & $\theta 00$ & & $0 ? 0$ & $\begin{array}{ll}\theta & 0\end{array}$ & & & & $\theta$ & \\
\hline $26-2,49-51$ & ०० & 0 & $\theta \theta$ & $\theta ? \theta \theta ? \theta$ & & & $\theta$ & $\theta$ & \\
\hline $26, \mathrm{CC}$ & $0 \theta 00$ & $\mathrm{O}$ & $0 \theta$ & 00 & & $\theta ?$ & $\theta$ & & \\
\hline $27-2,39-41$ & 000 & & 00 & $\theta$ & & & O & & \\
\hline $27, \mathrm{CC}$ & $\theta \theta$ & & $\begin{array}{ll}\theta & 0\end{array}$ & & & & & & \\
\hline $28-2,40-42$ & $\theta 00$ & & $0 \theta 00$ & $\theta 0$ & & & & & \\
\hline $28, \mathrm{CC}$ & $\theta$ & 0 & 000 & $\theta$ & & 00 & $\theta$ & $\theta$ & \\
\hline $29-2,56-58$ & $\theta \theta$ & 0 & $\theta \bullet ০ \theta$ & 00 & & & & $\theta$ & \\
\hline $29, \mathrm{CC}$ & $\theta \theta$ & 0 & $\theta ? \theta$ & $\theta$ & & 0 & 0 & 0 & \\
\hline $30-2,30-32$ & $\ominus \ominus \ominus$ & 0 & 000 & - & $\theta$ & 0 & $0 \theta$ & $\theta$ & \\
\hline $30, \mathrm{cc}$ & $\theta 0 \theta$ & 0 & $\theta 0 \theta$ & 00 & & 00 & $\theta 0$ & $\theta$ & \\
\hline $31-2,25-27$ & $\theta 00$ & & $\theta \theta \theta$ & $\theta \theta \theta$ & O & $\theta$ & $\theta$ & $\theta$ & \\
\hline $31, \mathrm{cc}$ & 00 & 0 & $\theta 000$ & $\theta \theta$ & & 00 & & $0 \theta$ & \\
\hline $32-2,50-51$ & 웅 & 0 & 0000 & ০?० & 0 & 0 & $\ominus$ & $\ominus$ & \\
\hline $32, \mathrm{cc}$ & $\theta 00$ & 0 & - $\ominus$ & 00 & & 0 & $\theta$ & $\theta \theta$ & \\
\hline $33-2,38-40$ & 000 & 0 & $\theta \theta ? \theta$ & $\theta$ & & 0 & & $\theta 0$ & \\
\hline $33, \mathrm{CC}$ & $\theta \theta$ & 0 & $\theta 0$ & $\theta ? \theta \ominus 0$ & $\theta 0$ & $\theta$ & $\theta$ & $\theta 0 \epsilon$ & \\
\hline $34-2,130-132$ & 0 & 0 & 0 & $0 ? 00 \theta$ & & 0 & 0 & $\theta \theta$ & \\
\hline $34, \mathrm{CC}$ & $\theta \theta$ & 0 & 0 & $\theta \theta 0$ & 0 & & 0 & $\theta$ & \\
\hline $35-1,113-115$ & $\theta \theta 0$ & 0 & $\theta$ & $\theta \theta$ & $\theta$ & & & $0 \theta t$ & \\
\hline $35, \mathrm{Cc}$ & $\theta \ominus$ & 0 & $\theta$ & 000 & & 0 & $\bullet$ & 00 & \\
\hline $36-1,97-99$ & $\theta$ & 0 & O? & 0 & & O? & 0 & 00 & \\
\hline $36-2,97-99$ & $\theta \theta \theta$ & 0 & $\theta ?$ & 00 & & & 0 & 0 & \\
\hline $36, \mathrm{CC}$ & & 00 & $\bullet 0 ?$ & $0 \ominus 0$ & & & 0 & 0 & \\
\hline $37-2,50-52$ & 000 & 000 & & $0 \theta$ & & & $\theta$ & $\theta$ & \\
\hline $37, \mathrm{CC}$ & 00 & 000 & 0 O? & $\theta \ominus 0$ & & & $\theta$ & 0 & \\
\hline $38-2,32-34$ & 00 & 00 & $\theta \theta ?$ & $\theta \theta$ & $\theta$ & & $\theta$ & & \\
\hline $38, \mathrm{cc}$ & 00 & 00 & & $\theta 0$ & & & & & \\
\hline $\begin{array}{l}30-2,59-61 \\
31-1,49-51\end{array}$ & $\theta \theta \stackrel{\theta}{\theta}$ & $0_{0}^{\circ}$ & $\begin{array}{l}0 ? \\
\theta\end{array}$ & $\begin{array}{l}\theta \theta 0 \\
\theta \ominus \theta ?\end{array}$ & $\begin{array}{l}\mathrm{O}_{\theta} \\
\mathrm{O}\end{array}$ & 0 & $\stackrel{\theta}{\ominus}$ & $0 \theta$ & $\begin{array}{l}\theta \theta \\
\theta \theta\end{array}$ \\
\hline
\end{tabular}

Abundant

Common

○ Few

? Tentative indentification

Figure 5. Planktonic foraminifers in Cores 14 through 38 of Hole 522 and Cores 30 and 31 of Hole 522A. 


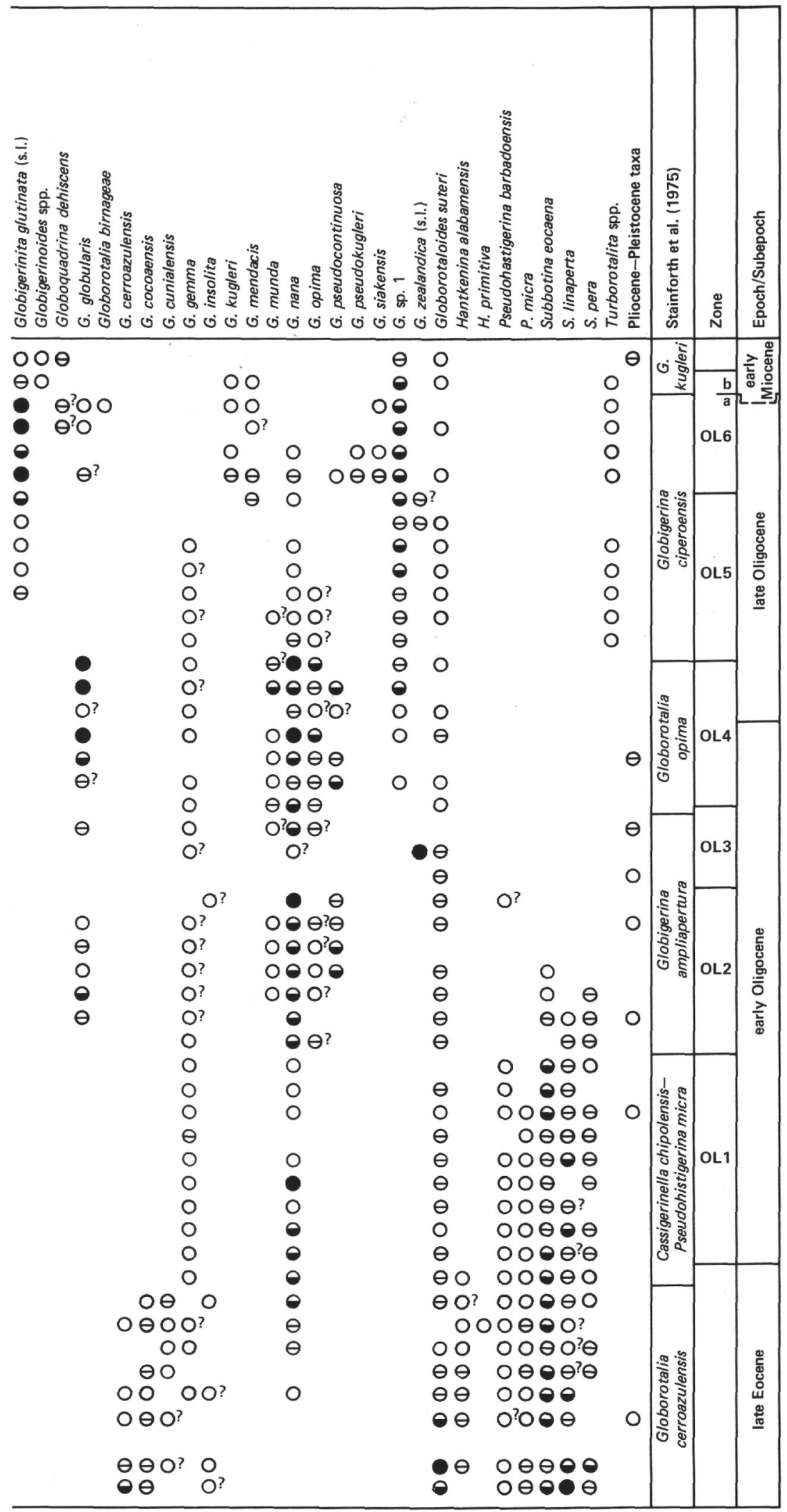

Figure 5. (Continued). 


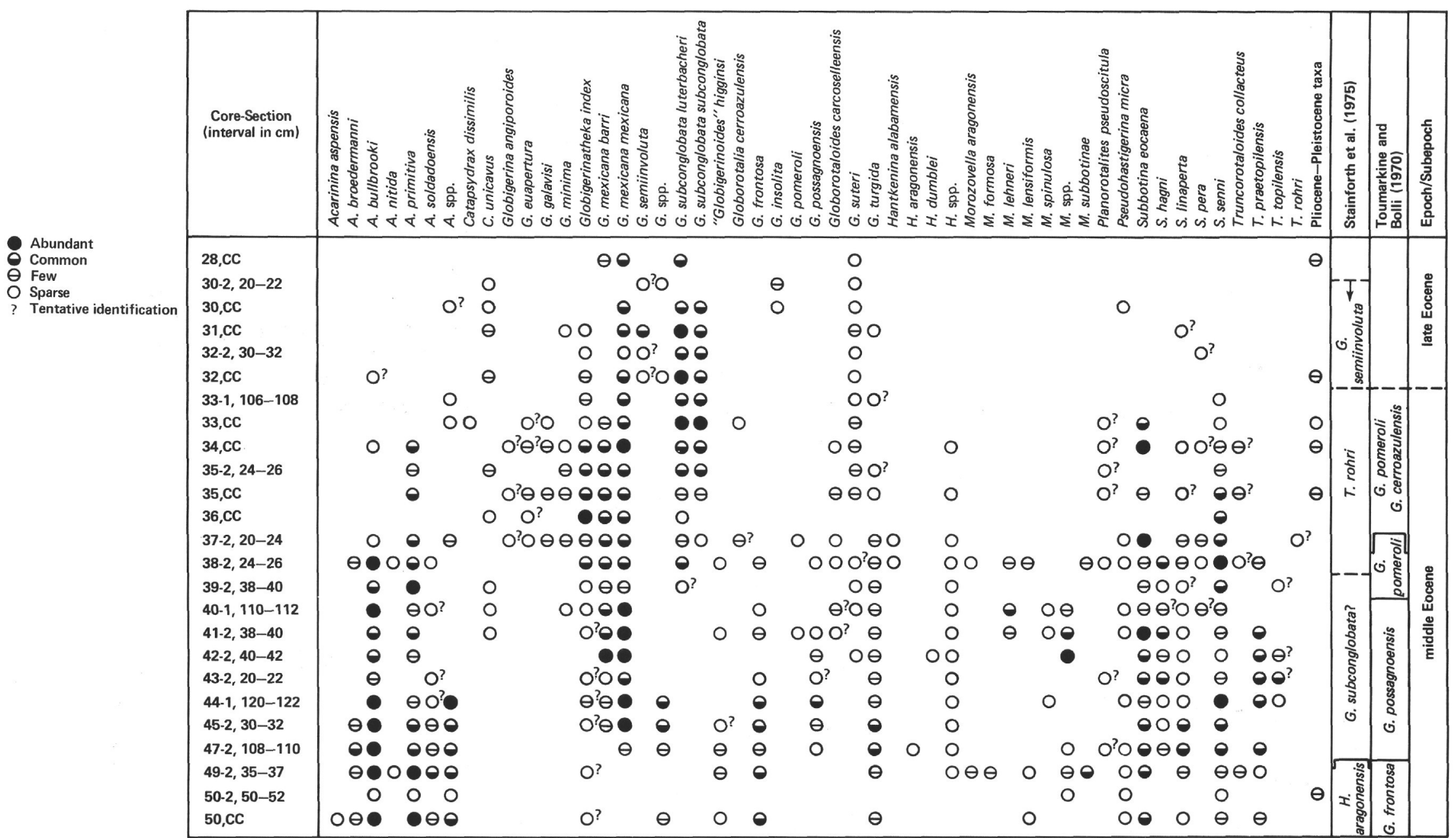

Figure 6. Occurrence of planktonic foraminifers in Cores 28 through 50 of Hole 523. 
blages from Cores 28 through 37 show marked dissolution. In fact, washed residues from Cores 28 through 32 consist almost exclusively of specimens and fragments of the robust genus Globigerinatheka. Planktonic foraminifers are abundant and moderately well preserved in samples from Cores 38 through 50 .

The interpretation of the faunal assemblages from the lower part of Hole 523 is complicated by the absence of several primary zone indicators, apparent reworking, downhole contamination, and dissolution. The association of Morozovella subbotinae and M. formosa with Hantkenina and Pseudohastigerina micra in Sample $523-49-2,35-37 \mathrm{~cm}$ is anomalous and is considered to represent the reworking of early Eocene taxa into middle Eocene sediments.

The first (lowest) occurrence of Globigerinatheka mexicana (s.1.) in Sample 523-47-2, 108-110 cm marks the base of the $G$. subconglobata Zone, and samples below Core 47, which contain P. micra, are referred to the Hantkenina aragonensis Zone. The first occurrence of unequivocal $G$. subconglobata luterbacheri in Sample $523-37-2,20-24 \mathrm{~cm}$ is used to approximate the lower limit of the Truncorotaloides rohri Zone, whereas the last occurrence of Acarinina, followed by the first occurrence of $G$. semiinvoluta, is used to establish the upper limit of the $T$. rohri Zone near the base of Core 32 . The highly dissolved nature of the assemblages above Core 32 precludes reliable identification of the top of the G. semiinvoluta Zone.

The Globorotalia cerroazulensis bioseries is relatively well represented in the lower part of Hole 523 and provides an alternative method for subdividing the middle Eocene. Thus, the first occurrence of $G$. possagnoensis, last occurrence of $G$. frontosa, first occurrence of $G$. cerroazulensis, and last occurrence of Acarinina are used to recognize the $G$. frontosa through $G$. pomeroli/ G. cerroazulensis Zones of Toumarkine and Bolli (1970). Note that the interpretation shown in Figure 6 assumes that the occurrence of $G$. frontosa in Core 38 is due to reworking.

\section{MIDDLE MIOCENE ZONATION}

The standard zonation of Blow (1969) incorporates the first occurrences of Sphaeroidinellopsis subdehiscens and Globigerina nepenthes to define the bases of Zones N13 and N14, respectively. In addition, G. dru$r y i$, the ancestor of $G$. nepenthes, was considered by Blow (1969) to have its first appearance near the top of Zone N11. Data from Holes 520 and 521, however, show that these taxa range down at least into Zone N8.

In Hole 520, S. subdehiscens, G. druryi, and forms very similar to $G$. nepenthes occur with calcareous nannofossils of the Sphenolithus heteromorphus Zone (NN5) (Percival, this vol.). Most calibrations of foraminifer and calcareous nannofossil zones show that the top of Zone NN5 falls within foraminifer Zone N11 (e.g., Barron et al., 1981). In Hole 521, Sphaeroidinellopsis subdehiscens, G. druryi, and forms close to $G$. nepenthes occur with calcareous nannofossils indicative of Zones NN4 and NN5 and with foraminifers indicative of Zones N8 and N9 (Fig. 4).
Middle Miocene faunas from Holes 520 and 521 show clear evidence of dissolution, and representatives of $S$. subdehiscens do not have the thick glassy cortex typical of well preserved Sphaeroidinellopsis. However, the specimens are compact, well rounded, have three chambers in the final whorl, and exhibit a straight, slitlike aperture that is often bordered by a rudimentary flange (see Pl. 1). The test wall is thickened and appears smooth when viewed with the light microscope. The forms I have referred to $S$. subdehiscens in Holes $\mathbf{5 2 0}$ and 521 could be confused with $G$. woodi connecta, but $G$. woodi connecta has a coarse, reticulate surface texture and a low-arched aperture with a lip. Specimens of S. subdehiscens occur throughout Core 29 of Hole 520 and in most samples examined from Cores 17 through 21 of Hole 521 (Figs. 3 and 4). Thus, I do not think that the occurrences of S. subdehiscens in Holes 520 and 521 are due to downhole contamination; rather, these occurrences reflect a real extension of its range. Srinivasan and Kennett (1981) also noted the presence of $S$. subdehiscens sensu Blow (1969) in the lower Miocene sediments of the Pacific basin.

G. druryi is ubiquitous and well developed in the basal middle Miocene assemblages from Hole 521, and these occurrences corroborate the finding of Srinivasan and Kennett (1981) that $G$. druryi extends down into the lower Miocene at Pacific Sites 281, 206, and 289. The occurrence of $G$. nepenthes in the middle Miocene sediments of Holes 520 and 521 is sporadic, and many specimens tentatively referred to $G$. nepenthes could easily be considered to be forms transitional between $G$. druryi and $G$. nepenthes. Other specimens, however, like that shown in Plate 1, Figure 10, exhibit the thumblike final chamber that is typical of $G$. nepenthes. To be conservative, I have questioned my identification of $G$. nepenthes from the Zone N8 and Zone N9 interval of Hole 521.

Brönnimann and Resig (1971) described G. nepenthoides from the lower to lower middle Miocene sediments of western equatorial Pacific DSDP Sites 64 and 62. Some of their illustrations of $G$. nepenthoides are extremely similar to illustrations of $G$. nepenthes from younger horizons in the same sites. For example, compare the illustrations in Plates 1 and 7 of Brönnimann and Resig (1971). Thus, it is evident that forms that are very similar, if not identical, to $G$. nepenthes occur much earlier than the late middle Miocene horizon normally associated with the base of Zone N14.

The data summarized above indicate that Zone N13 as defined by Blow (1969) can no longer be used as a standard biostratigraphic zone. In addition, correlations based on the first occurrence of $G$. nepenthes should be treated with caution. More lower to middle Miocene sequences should be studied to evaluate the reliability of using $G$. nepenthes as a primary zonal marker.

\section{OLIGOCENE ZONATION}

It was difficult to apply established standard zonations to the midlatitude Oligocene sequence of Hole 522. Difficulty in establishing the taxonomic limits of 
Globigerina tapuriensis and G. sellii, coupled with the sporadic occurrence or absence of several small Globigerina such as $G$. ciperoensis and $G$. angulisuturalis, preclude the use of the P zones of Blow $(1969,1970)$. The fourfold zonation of Stainforth et al. (1975) can be recognized in the Hole 522 assemblages, but determining the base of the Globorotalia opima opima Zone is complicated by the difficulty of identifying the earliest “typical" specimens of G. opima opima. Figure 5 suggested a sixfold subdivision of the Hole 522 Oligocene assemblages. The zonation finally developed (Zones OL1 to OL6) incorporates elements of both the standard tropical zonation of Stainforth et al. (1975) and elements of extra-tropical zonations (e.g., Jenkins, $1966,1971)$. I consider this zonation informal because it is based primarily on the sequence of events in Hole 522 . Therefore formal names and stratotypes are not given for the zones. The informal zones are described below from oldest to youngest, and the correlation between this zonation and other commonly used zonations is shown in Figure 7.

\section{Zone OL1}

Base-highest occurrence of either Globorotalia cerroazulensis (s.1.) or Hantkenina spp.

Top-Highest occurrence of Pseudohastigerina.
Comments-Most compilations of upper Eocene to lower Oligocene planktonic foraminifer ranges indicate that the last specimens of Hantkenina occur either prior to (Blow, 1969) or at the same time as the last Globorotalia cerroazulensis (s.1.) (Stainforth et al., 1975; Stainforth and Lamb, 1981). Hantkenina ranges slightly above G. cerroazulensis (s.1.) in Hole 522, and there is no reason to believe that the Hanktenina specimens in the upper section of Core 36 are reworked. Thus, it may be that Hantkenina survives G. cerroazulensis (s.1.) in some areas. The base of Zone OL1 is defined by the highest occurrence of either G. cerroazulensis (s.l.) or Hantkenina, whichever is highest. Using this criterion to define the base of OL1 maintains the biostratigraphic nature of the zone yet allows for the minor differences in the local stratigraphic ranges of these well known taxa.

The first occurrence of Globigerina ciperoensis probably falls in OL1. It may prove useful to use this event to divide OL1 into two subzones.

\section{Zone OL2}

Base-Highest occurrence of Pseudohastigerina. tura.

Top-Highest occurrence of Globigerina ampliaper-

Comments-The last occurrences of Globigerina ampliapertura and $G$. angiporoides are distinct events in the succession of faunas from Hole 522. G. angipo-

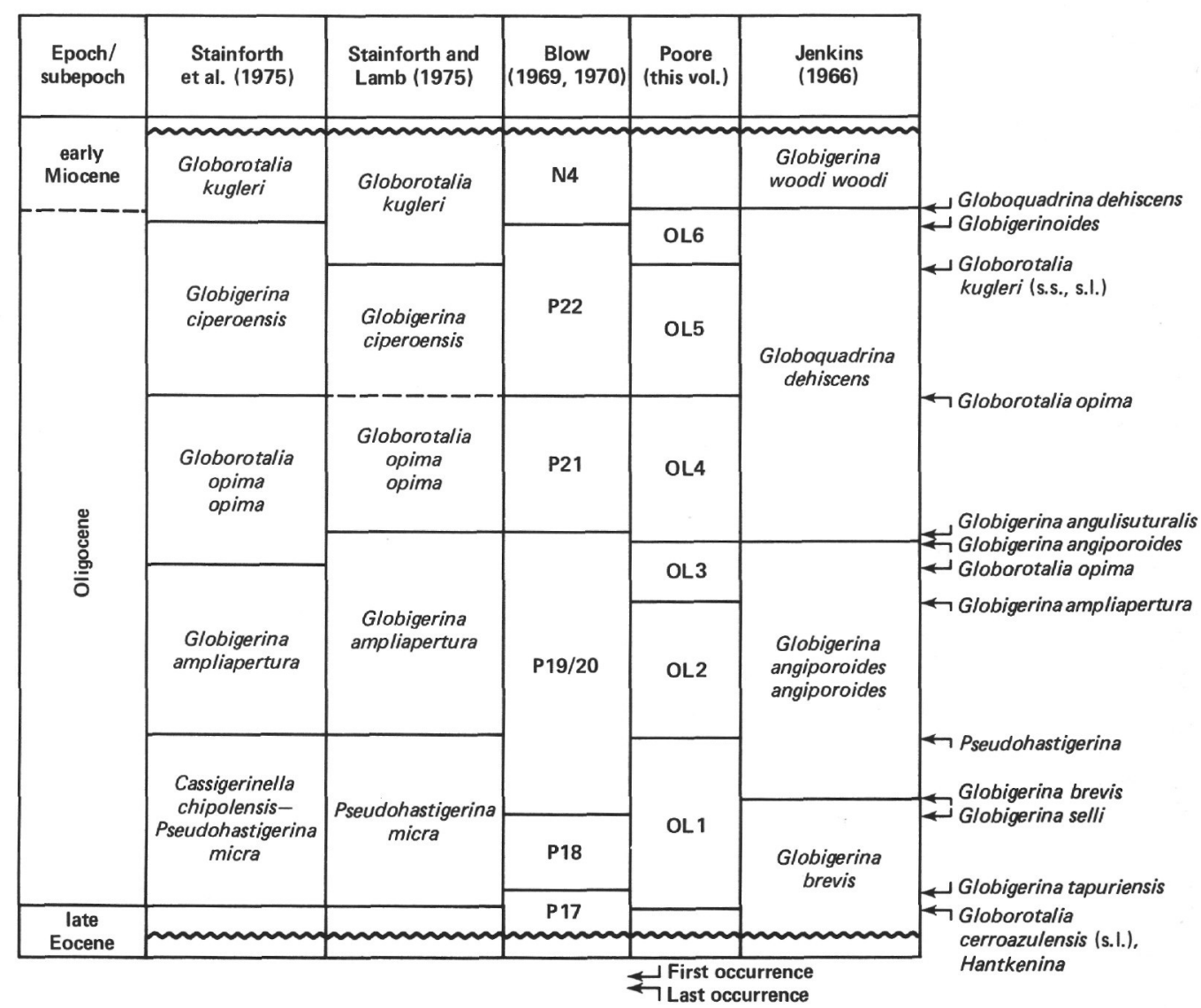

Figure 7. Correlation of selected tropical and extratropical zonations for the Oligocene. Biostratigraphic events used to define zone boundaries are shown on the right. Placement of limits of Oligocene follows this study. 
roides is usually a prominent component of extra-tropical faunas, and its extinction is used as a boundary marker in the zonation developed for the New Zealand region (Jenkins, 1966). In tropical regions, G. angiporoides has an abbreviated stratigraphic range and usually disappears before the extinction of $G$. ampliapertura (e.g., Stainforth et al., 1975, fig. 16). Additional magnetostratigraphic calibrations like that for Hole 522 (Poore et al., this vol.) will be necessary to evaluate the extent of the temporal variation in the last occurrences of $G$. ampliapertura and $G$. angiporoides across latitudinal gradients.

\section{Zone OL3} tura.

Base-Highest occurrence of Globigerina ampliaperdes.

Top-Highest occurrence of Globigerina angiporoi-

Comments-See above.

\section{Zone OL4} des.

Base-Highest occurrence of Globigerina angiporoi$m a$.

Top-Highest occurrence of Globorotalia opima opi-

Comments-Although a few specimens that are transitional between Globorotalia opima opima and G. opima nana occur in Core 20 and in Sample 522-19,CC, the last occurrence of "typical" G. opima opima is a well defined event in Core 21 of Hole 522.

The last occurrence of Chiloguembelina cubensis, which has been proposed as a reliable correlation event by a number of workers (e.g., Berggren, 1971) may prove to be useful for subdividing Zone OL4. C. cubensis occurs sporadically toward the upper limit of its range in Hole 522, so it is difficult to identify its extinction level. If the isolated occurrence in Sample 522$20, \mathrm{CC}$ is considered to be the result of reworking, the last $C$. cubensis occurs within Zone OL4. Additional documentation of the upper limit of $C$. cubensis will be necessary before its last appearance can be used to subdivide Zone OL4.

\section{Zone OL5} ma. (s.l.).

Base-Highest occurrence of Globorotalia opima opi-

Top-Lowest occurrence of Globorotalia kugleri

Comments-In Hole 522, the lowest specimens of Globorotalia kugleri and G. pseudokugleri appear in the same sample, although other studies (e.g., Stainforth and Lamb, 1981) indicate that G. pseudokugleri occurs prior to G. kugleri. If it becomes clear that there is a significant separation between the lowest occurrences of G. kugleri and G. pseudokugleri, the definition of the OL5/OL6 boundary may require revision.

\section{Zone OL6} (s.l.).
Top-Lowest occurrence of Globoquadrina dehiscens.

Comments-Globoquadrina dehiscens is used to mark the top of OL6 because the taxon is distinctive and resistant to dissolution. Recent studies in the Pacific Basin (Srinivasan and Kennett, 1981; Keller, 1981a, b) have found the lowest occurrence of $G$. dehiscens to be a reliable marker over a broad geographic area.

Although the origin of the genus Globigerinoides, which is used as a zonal boundary by a number of workers (Blow, 1969; Stainforth et al., 1975; Srinivasan and Kennett, 1981), occurs within the range of Globorotalia kugleri, I prefer to use the lowest occurrence of Globigerinoides to separate Zone OL6 into Subzones a and b. Globigerinoides is very susceptible to dissolution, and there is some disagreement concerning the lowest occurrence of the genus. Srinivasan and Kennett (1981) indicate that the lowest occurrence of Globigerinoides is well above the lowest occurrence of Globorotalia kugleri, whereas Keller (1981a) indicates. that the two taxa occur at nearly the same time. A few studies (e.g., Stainforth and Lamb, 1981) indicate that the lowest occurrence of Globigerinoides significantly precedes the lowest occurrence of Globorotalia kugleri. Data from Hole 522 cannot be used to establish the ultimate lowest occurrence of Globigerinoides, because its lowest occurrence in Hole 522 is almost certainly controlled by dissolution. Another problem with using the Globigerinoides datum involves differing concepts of the morphologic limits of Globigerinoides. Additional stratigraphic and taxonomic work on nondissolved sequences is needed to establish the ultimate lower stratigraphic limit of Globigerinoides. Biostratigraphic recognition of the Oligocene/Miocene boundary is equivocal (Berggren et al., in press). Thus, some workers would assign Zone OL6 to the Miocene. I consider OL6 to be mostly Oligocene because of the close association of the last occurrence of Reticulofenestra bisecta with the first occurrence of Globoquadrina dehiscens in Hole 522.

\section{OLIGOCENE PLANKTONIC FORAMINIFERAL DIVERSITY}

Data from the apparently complete Oligocene sequence recovered at Site $\mathbf{5 2 2}$ as well as information from other recent studies offer new insights into the diversity of Oligocene planktonic foraminifers. The Oligocene has been characterized as a time of drastically reduced diversity and the widespread occurrence of a single cosmopolitan globigerine planktonic foraminifer assemblage (Cifelli, 1969). The ubiquitous occurrence of this low-diversity globigerine assemblage has been used to infer a lack of thermal gradients and the presence of uniformly cool surface-water conditions throughout the Oligocene oceans. A slightly different view has been that the low diversity of the faunas resulted from a climatic deterioration during the Oligocene (Berggren, 1969; Kennett, 1978; Keigwin, 1980).

The concept of a uniform cosmopolitan, low-diversity globigerine assemblage, or lack of faunal provincialism, during the Oligocene is not supported by re- 
cent qualitative and semiquantitative DSDP results. At least three readily identifiable faunal provinces are present in the Southern Hemisphere during Oligocene. A distinct polar, or Antarctic faunal assemblage consisting of Globigerina angiporoides and Catapsydrax dissimilis was recovered during DSDP Leg 28 (Kaneps, 1975). Oligocene assemblages from the subantarctic region (DSDP Sites 277 and 282) are clearly more diverse. Most samples yield 4 to 8 taxa, with the uppermost Oligocene samples occasionally yielding more than 10 taxa (Jenkins, 1975). In contrast, assemblages from the relatively undissolved portions of Hole 522, which probably represent a temperate or cool-subtropical faunal province, usually contain more than 20 taxa.

Data from the North Atlantic also suggest that species diversity declines with increasing latitude and that faunal provinces existed during the Oligocene. Only a few taxa are recorded in the Oligocene assemblages from DSDP Hole 112 in the northwestern Atlantic (Laughton, Berggren, et al., 1972, pp. 153-154). Oligocene assemblages from DSDP Holes 116 and 117 in the northeastern Atlantic are more diverse, but the diversity is still low (Laughton, Berggren, et al., 1972). In fact, the low diversity of these assemblages and lack of characteristic low-latitude zonal markers led Berggren (1972) to informally propose a high-latitude zonation for this region. Oligocene faunas from DSDP Site 407, off Iceland, on the other hand, contain 10 to 15 species per sample, although the assemblages are dominated by one or two species (Poore, 1979, table 2). In addition, a quantitative study of the distribution of planktonic foraminifers in the Atlantic Basin identified three Oligocene biogeographic assemblages (Haq et al., 1977).

Thus, current data indicate that there were clear differences and gradients in diversity between high- and low-latitude planktonic foraminifer faunas during the Oligocene and that distinct faunal provinces were present.

A second point concerns the putative drastic reduction of diversity during the Oligocene as compared with other times during the Cenozoic. The diversity of planktonic foraminifers in a particular epoch or subepoch is, in large part, a function of the amount of individual and collective interest in and effort directed toward that interval by micropaleontologists. For example, publication of the work of Blow (1979) has greatly increased the number of taxa in the Danian assemblage, which has traditionally been considered impoverished. As another example, the "conservative" approach of Saito et al. (1981) recognizes over 100 taxa in the Quaternary. Thus, it is often difficult to judge changes in diversity when data from different sources are used. In order to assess the nature of planktonic foraminifer diversity during the Oligocene, consider the following comparisons of middle Eocene, Oligocene, and Pliocene diversity data from Leg 73 and of middle Eocene and Oligocene diversity data from equatorial Atlantic DSDP Site 366.

The moderately well preserved assemblages from Cores 28 to 35 of Hole 522 often contain 20 or more taxa per sample (Fig. 5). I consider these tabulations
Table 2. Comparison of diversity by zone in middle Eocene and Oligocene of Site 366. Data are from Krasheninnikov and Pflaumann (1978, table 2).

\begin{tabular}{llc}
\hline \multicolumn{1}{c}{ Zone } & $\begin{array}{c}\text { Number } \\
\text { of taxa }\end{array}$ \\
\hline Oligocene & Globorotalia kugleri & 15 \\
& Globigerina ciperoensis & 19 \\
& Globorotalia opima & 22 \\
& Globigerina ampliapertura & 17 \\
& Globigerina sellii & 21 \\
middle Eocene & Globigerina tapuriensis & 21 \\
& Truncorotaloides rohri & 20 \\
& Orbulinoides beckmanni & 21 \\
& Globorotalia lehneri & 22 \\
& Globigerapsis kugleri & 18 \\
& Hantkenina aragonensis & 18 \\
\hline
\end{tabular}

minimum estimates, because it is likely that at least two taxa are included under Globorotalia gemma and because the taxonomy of large globigerinids has been treated conservatively (see Taxonomic Notes). The diversity of the middle Eocene assemblages from the moderately well preserved portion of Hole 523 is also about 20 taxa per sample (Fig. 6). Moreover, assemblages from the moderately well preserved lower Pliocene sequence of Hole 519 contain 25 to 30 species per sample (Table 2). Thus, there is little difference in diversity between the middle Eocene, Oligocene, and lower Pliocene assemblages recovered from the South Atlantic during Leg 73.

Table 2 shows a comparison of diversity by zone between the middle Eocene and Oligocene assemblages recovered at DSDP Site 366 as recorded in table 2 of Krasheninnikov and Pflaumann (1978). Table 2 also suggests little difference in diversity between the middle Eocene and Oligocene planktonic foraminifer assemblages at this equatorial site.

These comparisons show that the diversity of planktonic foraminifers in some mid- and low-latitude areas was not very different during the Oligocene than during other times in the Cenozoic. Thus, the idea that all planktonic foraminifer diversity was drastically reduced during the Oligocene should be re-evaluated.

\section{ACKNOWLEDGMENTS}

I thank John Barron and Tom Gibson for constructive comments on a draft of this manuscript. I also thank Judy Junkman for technical support and help in identifying Neogene faunas for this report.

\section{REFERENCES}

Barron, J. A., Poore, R. Z., and Wolfart, R., 1981. Biostratigraphic summary, Deep Sea Drilling Project Leg 63. In Yeats, R. S., Haq, B. U., et al., Init. Repts. DSDP, 63: Washington (U.S. Govt. Printing Office), 927-941.

Berggren, W. A., 1969. Rates of evolution in some Cenozoic planktonic foraminifera. Micropaleontology, 15:351-365. 1971. Multiple phylogenetic zonations of the Cenozoic based on planktonic foraminifera. In Farinacci, A. (Ed.), Proc. Second Planktonic Conf.: Rome (E. Tecnoscienza), pp. 41-56. 1972. Cenozoic biostratigraphy and paleobiogeography of the North Atlantic. In Laughton, A. S., Berggren, W. A., et al., Init. Repts. DSDP, 12: Washington (U.S. Govt. Printing Office), 965-1001. 
1973. The Pliocene time scale: calibration of planktonic foraminiferal and calcareous nannoplankton zones. Nature, 243: 391-397.

1977. Late Neogene planktonic foraminiferal biostratigraphy of the Rio Grande Rise (South Atlantic). Mar. Micropaleontol., 2:265-313.

Berggren, W. A., Kent, D. V., and Flynn, J. J., in press. Paleogene geochronology and chronostratigraphy. In Snelling, N. J. (Ed.), Geochronology and the Geologic Record, Spec. Publ. Geol. Soc. London.

Blow, W. H., 1969. Late middle Eocene to Recent planktonic foraminiferal biostratigraphy. In Bronnimann, P., and Renz, H. H. (Eds.), Proc. First Planktonic Conf.: Leiden (E. J. Brill), pp. 199-422.

1970. Validity of biostratigraphic correlations based on the Globigerinacea. Micropaleontology, 16:257-268.

1979. The Cainozoic Globigerinida (Parts 1-III): Leiden (E. J. Brill).

Brönnimann, P., and Resig, J., 1971. A Neogene Globigerinacean biochronology time-scale of the southwestern Pacific. In Winterer, E. L., Riedel, W. R., et al., Init. Repts. DSDP, 7 (Pt. 2): Washington (U.S. Govt. Printing Office), 1235-1469.

Cifelli, R. 1969. Radiation of Cenozoic planktonic foraminifera. Systematic Zool., 18:154-168.

Haq, B. U., Premoli Silva, I., and Lohmann, G. P., 1977. Calcareous plankton paleobiogeographic evidence for major climatic fluctuations in the early Cenozoic Atlantic Ocean. J. Geophys. Res., 82:3861-3876.

Jenkins, D. G., 1966. Planktonic foraminiferal zones and new taxa from the Danian to lower Miocene of New Zealand. N. Z. J. Geol. Geophys., 8:1088-1126.

1971. New Zealand Cenozoic planktonic foraminifera. $N$. Z. Geol. Surv. Paleontol. Bull., 42:1-278.

1975. Cenozoic planktonic foraminiferal biostratigraphy of the southwestern Pacific and Tasman Sea-DSDP Leg 29. In Kennett, J. P., Houtz, R. E., et al., Init. Repts. DSDP, 29: Washington (U.S. Govt. Printing Office), 449-467.

Jenkins, D. G., and Orr, W. N., 1972. Planktonic foraminiferal biostratigraphy of the eastern Equatorial Pacific-DSDP Leg 9. In Hays, J. D., et al., Init. Repts. DSDP, 9: Washington (U.S. Govt. Printing Office), 1059-1193.

Kaneps, A. G., 1975. Cenozoic planktonic foraminifera from Antarctic deep-sea sediments, Leg 28, DSDP. In Hayes, D. E., Frakes, L. A., et al., Init. Repts. DSDP, 28: Washington (U.S. Govt. Printing Office), 573-583.

Keigwin, L. D., Jr., 1980. Paleoceanographic change in the Pacific at the Eocene-Oligocene boundary. Nature, 287:722-725.

Keller, G., 1981a. Miocene biochronology and paleoceanography of the North Pacific. Mar. Micropaleontol., 6:535-551.

1981b. Origin and evolution of the genus Globigerinoides in the early Miocene of the northwestern Pacific, DSDP Site 292. Micropaleontology, 27:293-304.

Kennett, J. P., 1978. The development of planktonic biogeography in the Southern Ocean during the Cenozoic. Mar. Micropaleontol., 3:301-345.

Krasheninnikov, V. A., and Hoskins, R. H., 1973. Late Cretaceous, Paleogene and Neogene planktonic foraminifera. In Heezen, B. C., MacGregor, I. D., et al., Init. Repts. DSDP, 20: Washington (U.S. Govt. Printing Office), 105-203.

Krasheninnikov, V. A., and Pflaumann, U., 1978. Zonal stratigraphy and planktonic foraminifers of Paleogene deposits of the Atlantic Ocean to the west off Africa (Deep Sea Drilling Project, Leg 41). In Lancelot, Y., Seibold, E., et al., Init. Repts. DSDP, 41: Washington (U.S. Govt. Printing Office), 581-611.

Laughton, A. S., Berggren, W. A., et al., 1972. Init. Repts. DSDP, 12: Washington (U.S. Govt. Printing Office).

Poore, R. Z., 1979. Oligocene through Quaternary planktonic foraminiferal biostratigraphy of the North Atlantic: DSDP Leg 49. In Luyendyk, B. P., Cann, J. R., et al., Init. Repts. DSDP, 49: Washington (U.S. Govt. Printing Office), 447-517.

Saito, T., Thompson, P. R., and Breger D., 1981. Systematic Index of Recent and Pleistocene Planktonic Foraminifera: Tokyo (Univ. Tokyo Press).
Srinivasan, M. S., and Kennett, J. P., 1981. Neogene planktonic foraminiferal biostratigraphy and evolution: Equatorial to Subantarctic, South Pacific. Mar. Micropaleontol., 6:499-533.

Stainforth, R. M., and Lamb, J. L., 1981. An evaluation of planktonic foraminiferal zonation of the Oligocene. Univ. Kansas Paleont. Contrib., 104:1-42.

Stainforth, R. M., Lamb, J. L., Luterbacher, H., Beard, J. H., and Jeffords, R. M., 1975. Cenozoic planktonic foraminiferal zonation and characteristics of index forms. Univ. Kansas Paleont. Contrib., 62:1-425.

Toumarkine, M., and Bolli, H. M., 1970. Évolution de Globorotalia cerroazulensis (Cole) dans L' Éocène moyen et superieur de Possagno (Italie). Rev. Micropaleontol., 13:131-145.

Date of Initial Receipt: September 27, 1982

\section{APPENDIX A \\ Taxonomic Notes}

\section{Catapsydrax cf. C. unicavus Bolli, Loeblich, and Tappan}

A large compact globigerinid occurring in several samples from the Oligocene of Hole 522 was considered to be related to Catapsydrax because of its coarse reticulate surface texture and a prominent umbilical bulla. Oxygen-isotope analyses of this taxon, however, demonstrate that it is a near-surface-dwelling form, whereas typical Catapsydrax are deep-dwelling forms (Poore and Matthews, this vol.). Additional work will be necessary to determine the taxonomic position of Catapsydrax cf. C. unicavus from Hole 522.

\section{Globigerinita glutinata (Egger)}

In this chapter, Globigerinita ambitacrena (Loeblich ahd Tappan), G. incrusta Akers, and G. naparimaensis Bronnimann are recorded as G. glutinata. Globigerina juvenilis Bolli, the ancestor of Globigerinita, is recorded as a separate taxon in the Oligocene prior to the development of populations of $G$. juvenilis in the late Oligocene that contain bullate individuals. As soon as bullate specimens are established in the populations, Globigerina juvenilis is also included in Globigerinita glutinata.

\section{Globorotalia gemma Jenkins}

Globorotalia gemma is a minute form that occurs throughout most of the Oligocene of Hole 522. In addition to typical forms (Pl. 3, Figs. 1-4), individuals with a smoother wall, a distinctive and wide umbilical pit, and more oval chambers were also recorded as G. gemma. It is likely that the forms will be separated after further work.

\section{Globorotalia grata (Todd)}

Globorotalia grata is a poorly known taxon that appears to have a wide geographic range. It has been recorded in the eastern equatorial Pacific as Globorotalia sp. 4 (Jenkins and Orr, 1972, pl. 18, figs. 7-12), and from the western equatorial Pacific as Globorotalia sp. (Krasheninnikov and Hoskins, 1973, pl. 21, figs. 10-12). The occurrence of G. grata in the Miocene of the midlatitude South Atlantic Site 521 suggests that it is present over a large part of the Atlantic Basin.

\section{Globorotalia sp. 1}

Small, smooth-walled forms noted in the Oligocene of Hole 522 that show a trend from trochospiral coiling to planispiral coiling upsection are recorded in Figure 5 as Globorotalia sp. 1. The form is highly variable, and more than one taxon may be present.

\section{Orbulina}

Orbulina universa d'Orbigny, O. suturalis Brönnimann, and Biorbulina are recorded as Orbulina spp. in Figures 2 to 4.

\section{Praeorbulina}

Praeorbulina recorded in Figure 4 includes Praeorbulina glomerosa (Blow) (s.l.) and P. transitoria (Blow).

\section{Pseudohastigerina barbadoensis Blow}

No attempt was made to distinguish Pseudohastigerina barbadoensis from $P$. naguewichiensis (Myatliuk) in this study. Both taxa are probably present in the lower Oligocene of Hole 522. 


\section{Subbotina eocaena (Gumbel)}

The taxonomy and stratigraphic extent of the large globigerinids of the Eocene and Oligocene is not well documented at this time. As was noted by Stainforth et al. (1975), it is unusual for any two workers to treat this group in the same manner, and at this time the biostratigraphic utility of these globigerinids is questionable. Because a detailed revision of this group is beyond the scope of this study, I have recorded a variety of large globigerinids as Subbotina eocaena.

\section{APPENDIX B \\ List of Species}

The species listed in Figures 2 to 6 include: Acarinina aspensis (Colom) 1954

A. broedermanni (Cushman and Bermudez) 1949

A. bullbrooki (Bolli) 1957

A. nitida (Martin) 1943

A. primitiva (Finlay) 1939

A. soldadoensis (Brönnimann) 1952

Candeina nitida d'Orbigny 1839

Cassigerinella chipolensis (Cushman and Ponton) 1932

Catapsydrax dissimilis ciperoensis (Blow and Banner) 1962

C. dissimilis dissimilis (Cushman and Bermudez) 1937

C. parvulus (Bolli, Loeblich, and Tappan) 1957

C. unicavus Bolli, Loeblich, and Tappan 1957

Chiloguembelina cubensis (Palmer) 1934

C. martini (Pijpers) 1933

Cribrohantkenina inflata (Howe) 1928

Globigerina ampliapertura Bolli 1957

G. angiporoides Hornibrook 1965

G. anguliofficinalis Blow 1969

G. angustiumbilicata Bolli 1957

G. apertura Cushman 1918

G. bulloides d'Orbigny 1826

G. calida Parker 1962

G. ciperoensis Bolli 1954

G. connecta Jenkins 1964

G. decoraperta Takayanagi and Saito 1962

G. digitata Brady 1879

G. druryi Akers 1955

G. euapertura Jenkins 1960

G. falconensis Blow 1959

G. galavisi Bermudez 1961

G. gortanii Borsetti 1959

G. incisa (Brönnimann and Resig) 1971

G. juvenilis Bolli 1957

G. minima Jenkins 1966

G. nepenthes Todd 1957

G. obesa (Bolli) 1957

G. officinalis Subbotina 1953

G. ouachitaensis Howe and Wallace 1932

G. praebulloides Blow 1959

G. praedehiscens (Blow and Banner) 1962

G. praedigitata Parker 1967

G. pseudobesa (Salvatorini) 1966

G. pseudociperoensis Blow 1969

G. pseudovenezuelana Blow and Banner 1962

G. rubescens Hofker 1956

G. sellii Borsetti 1959

G. tapuriensis Blow and Banner 1962

G. tripartita Koch 1926

G. utilisindex Jenkins and Orr 1973

G. woodi Jenkins 1960

Globigerinatheka index (Finlay) 1939

G. mexicana barri Brönnimann 1952

G. mexicana mexicana (Cushman) 1925

G. semiinvoluta (Keijzer) 1945

G. subconglobata luterbacheri Bolli 1972

G. subconglobata subconglobata (Shutskaya) 1958

G. tropicalis (Blow and Banner) 1962

Globigerinella aequilateralis (Brady) 1879

Globigerinita glutinata (Egger) 1893

G. iota Parker 1962

G. uvula (Ehrenberg) 1861

Globigerinoides bollii Blow 1959
G. conglobatus (Brady) 1879

" $G$." higginsi Bolli 1957

G. kennetti Keller and Poore 1980

G. obliquus Bolli 1957

G. pseudoruber Todd 1957

G. ruber (d'Orbigny) 1839

G. sacculifer (Brady) 1877

G. seigliei Bermudez and Bolli 1969

G. sicanus de Stefani 1952

G. subquadratus Brönnimann 1954

G. tenellus Parker 1958

Globoquadrina altispira (Cushman and Jarvis) 1936

G. dehiscens (Chapman, Parr, and Collins) 1934

G. globularis Bermudez 1961

Globorotalia anfracta Parker 1967

G. archaeomenardii Bolli 1957

G. birnageae Blow 1959

G. cavernula Bé 1967

G. cerroazulensis (Cole) 1928

G. cibaoensis Bermudez 1949

G. clemenciae (Bermudez) 1961

G. cocoaensis Cushman 1928

G. conoidea Walters 1965

G. conomiozea Kennett 1966

G. crassaformis (Galloway and Wissler) 1927

G. crassula Cushman and Stewart 1930

G. cunialensis Toumarkine and Bolli 1970

G. exilis Blow 1969

G. exserta Romeo 1969

G. fohsi Cushman and Ellisor 1939

G. frontosa (Subbotina) 1953

G. galapagosensis Quilty 1978

G. gemma Jenkins 1966

G. grata (Todd) 1957

G. hirsuta (d'Orbigny) 1839

G. inflata (d'Orbigny) 1839

G. insolita Jenkins 1966

G. kugleri Bolli 1957

G. lenguaensis Bolli 1957

G. limbata (Fornasini) 1902

G. margaritae Bolli and Bermudez 1965

G. mayeri Cushman and Ellisor 1939

G. menardii (Parker, Jones, and Brady) 1865

G. mendacis Blow 1969

G. merotumida Blow and Banner 1965

G. miocenica Palmer 1945

G. miozea Finlay 1939

G. multicamerata Cushman and Jarvis 1930

G. munda Jenkins 1966

G. nana Bolli 1957

G. opima Bolli 1957

G. peripheroronda Blow and Banner 1966

G. pertenuis Beard 1969

G. plesiotumida Blow and Banner 1966

G. pomeroli Toumarkine and Bolli 1970

G. possagnoensis Toumarkine and Bolli 1970

G. praehirsuta Blow 1969

G. praemenardii Cushman and Stainforth 1945

G. praescitula Blow 1959

G. pseudocontinuosa Jenkins 1967

G. pseudokugleri Blow 1969

G. pseudopumilio Brönnimann and Resig 1971

G. puncticulata (Deshayes) 1832

G. scitula (Brady) 1882

G. siakensis LeRoy 1939

G. tosaensis Takayanagi and Saito 1962

G. truncatulinoides (d'Orbigny) 1839

G. tumida (Brady) 1877

G. ungulata Bermudez 1961

G. zealandica Hornibrook 1958

Globorotaloides carcoselleensis Toumarkine and Bolli 1975

G. hexagona (Natland) 1938

G. suteri Bolli 1957

G. turgida (Finlay) 1939

Hantkenina alabamensis Cushman 1925 
H. aragonensis Nuttall 1930

H. dumblei Weinzierl and Applin 1929

H. primitiva Cushman and Jarvis 1929

Hastigerina pelagica (d'Orbigny) 1839

Morozovella aragonensis (Nuttall) 1930

M. formosa Bolli 1957

M. lehneri (Cushman and Jarvis) 1929

M. lensiformis (Subbotina) 1953

M. spinulosa (Cushman) 1927

M. subbotinae (Morozova) 1939

Neogloboquadrina acostaensis (Blow) 1959

N. dutertrei (d'Orbigny) 1830

N. humerosa (Takayanagi and Saito) 1962

N. pachyderma (Ehrenberg) 1861

Planorotalites pseudoscitulus (Glaessner) 1937

Pseudohastigerina barbadoensis Blow 1969

P. micra (Cole) 1927
Pulleniatina obliquiloculata (Parker and Jones) 1865 Sphaeroidinella dehiscens (Parker and Jones) 1865

Sphaeroidinellopsis seminulina (Schwager) 1866

S. subdehiscens (Blow) 1959

Subbotina eocaena (Gumbel) 1868

S. hagni (Gohrbandt) 1967

S. linaperta (Finlay) 1939

S. pera (Todd) 1957

S. senni (Beckmann) 1953

Truncorotaloides collacteus (Finlay) 1939

T. praetopilensis Blow 1979

T. rohri Bronnimann and Bermudez 1953

T. topilensis (Cushman) 1925

Turborotalita cristata (Heron-Allen and Earland) 1929

T. humilis (Brady) 1884

T. multiloba (Romeo) 1965

T. quinqueloba (Natland) 1938 

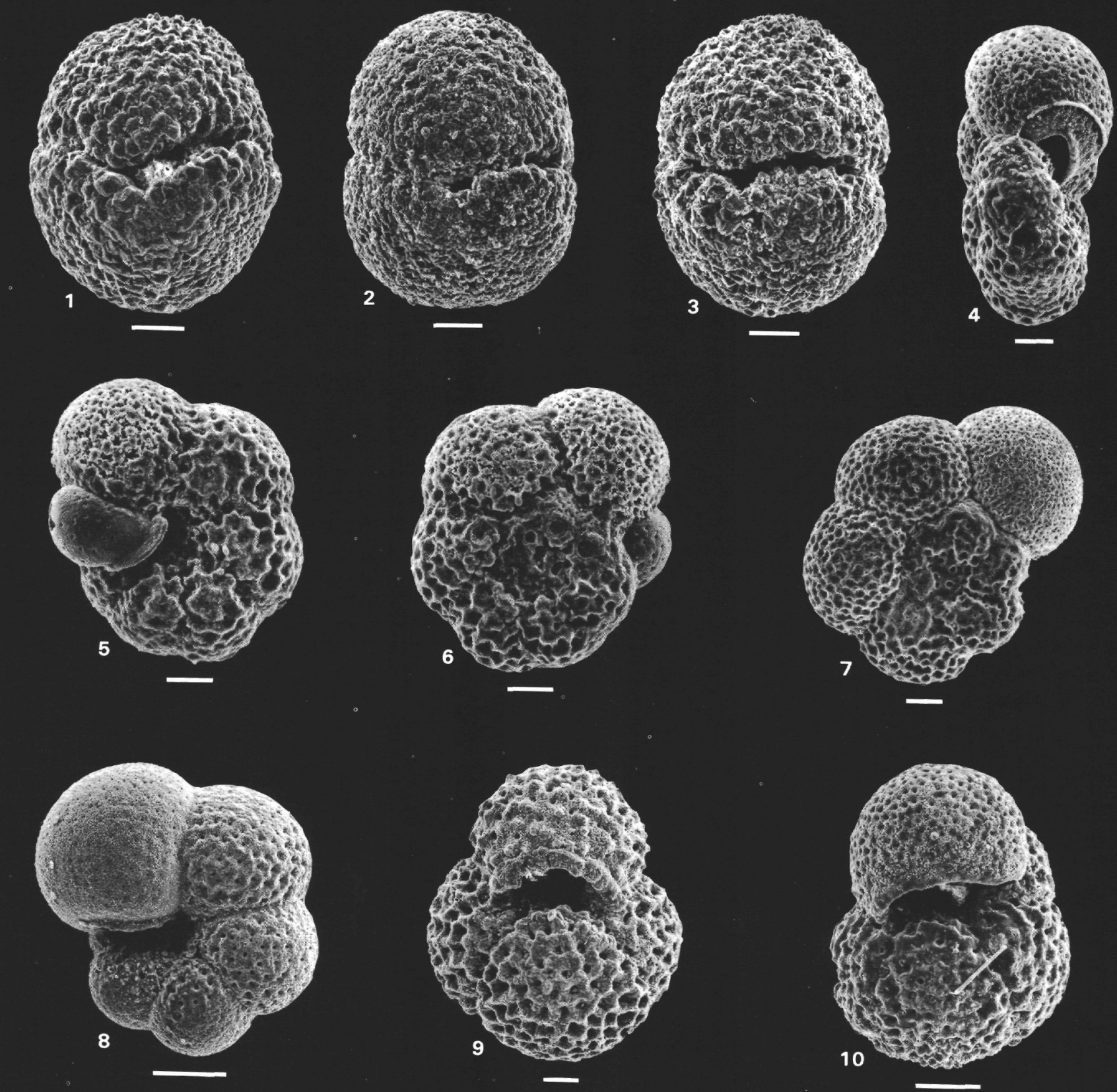

Plate 1. Miocene planktonic foraminifers from Holes 520 and 521. 1-3. Sphaeroidinellopsis subdehiscens Blow, all from Sample 520-29-2, 84-86 $\mathrm{cm}$, umbilical views, scale bars $=100 \mu \mathrm{m}$. 4-8. Globorotalia pseudopumilio Brönnimann and Resig, all from Sample 521-4,CC, scale bars $=30$ $\mu \mathrm{m}$. (4) Side view. (5) Umbilical view. (6) Spiral view of Fig. 5. (7) Spiral view. (8) Umbilical view. 9. Globigerina druryi Akers, Sample 521$19-3,14-16 \mathrm{~cm}$, umbilical view, scale bar $=10 \mu \mathrm{m} . \quad 10$. Globigerina nepenthes Todd?, Sample 521-19-3, 14-16 cm, umbilical view, scale bar $=$ $30 \mu \mathrm{m}$. 

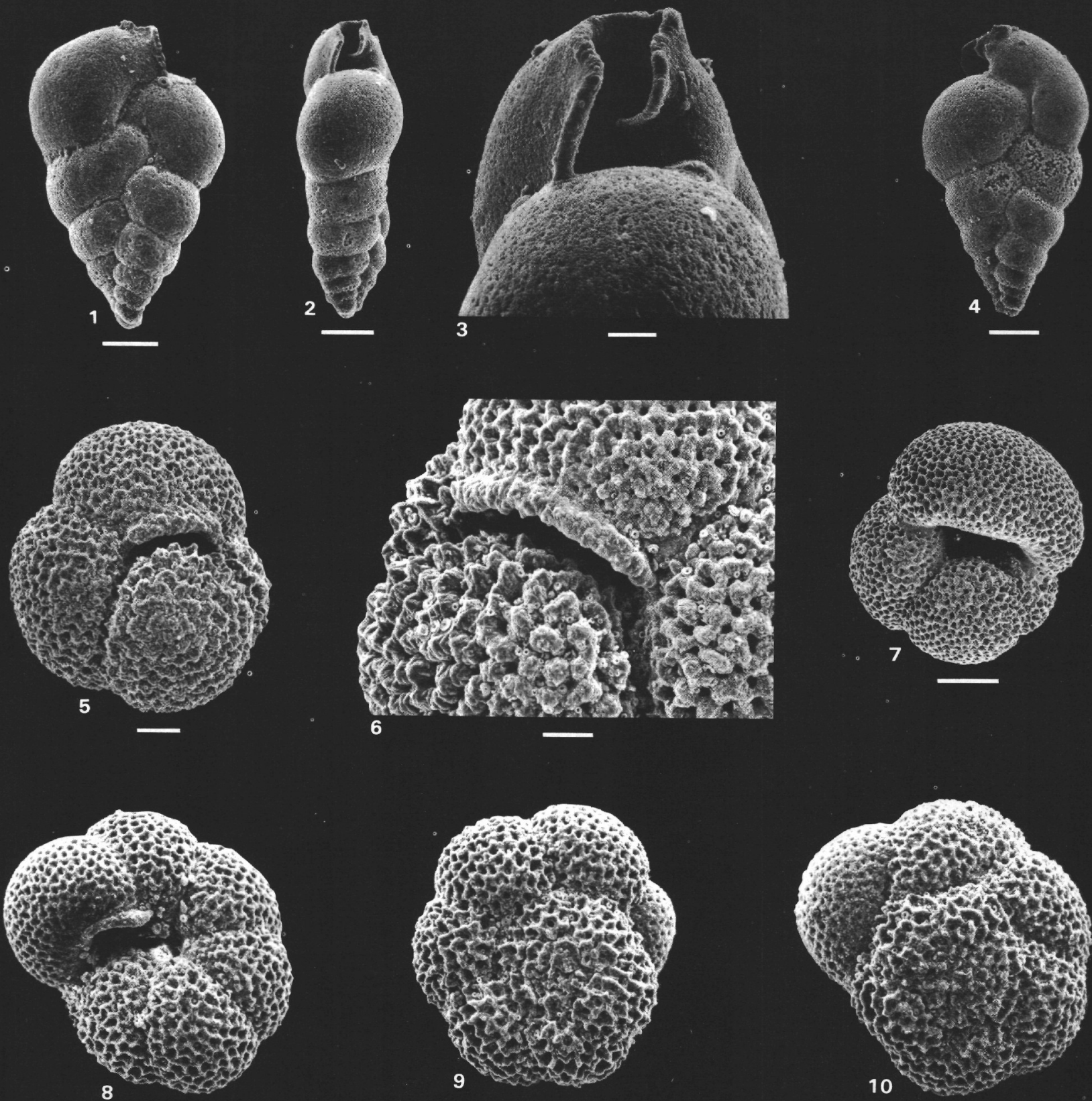

Plate 2. Late Eocene to Oligocene planktonic foraminifers from Hole 522. 1-4. Chiloguembelina martini (Pijpers), all from Sample 522-37,CC, scale bars $=30 \mu \mathrm{m}$. (1) Side view. (2) Edge view. (3) Detail of aperture. (4) Side view of Fig. 2. 5 and 6. Globigerina angiporoides Hornibrook, Sample 522-28,CC. (5) Umbilical view, scale bar $=100 \mu \mathrm{m}$. (6) Detail of umbilical region of different specimen. Note restricted aperture bordered by distinct lip. Scale bar $=30 \mu \mathrm{m}$. 7. Globigerina euapertura Jenkins, Sample 522-29,CC, umbilical view, scale bar $=100 \mu \mathrm{m}$. 8-9. Globorotalia pseudokugleri Blow, Sample 522-17-2, 105-107 cm, scale bars $=30 \mu \mathrm{m}$. (8) Umbilical view. (9) Spiral view. 10. Globorotalia kugleri Bolli, Sample 522-17-2, 105-107 cm, scale bar $=30 \mu \mathrm{m}$. Note curved sutures. 

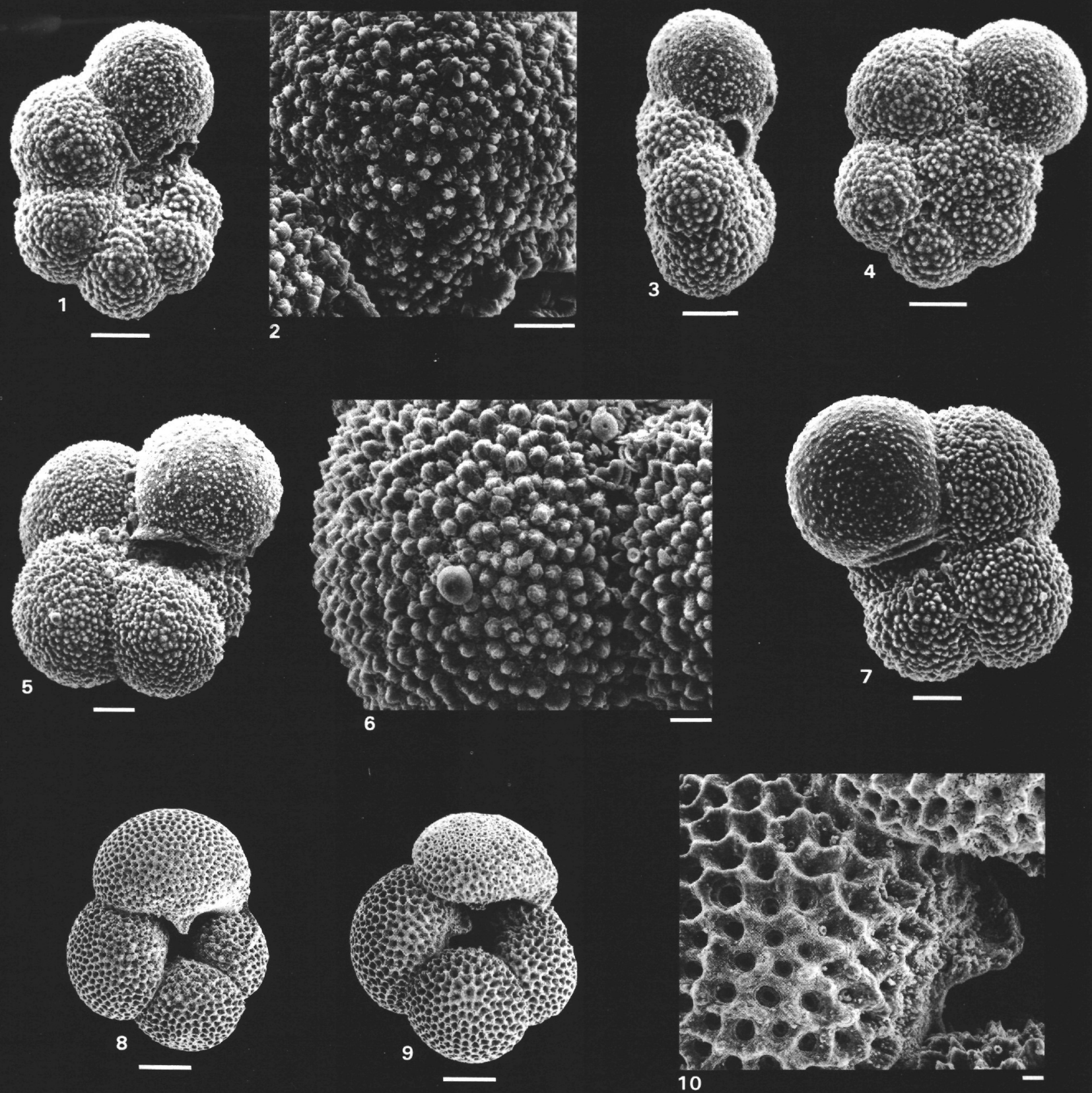

Plate 3. Oligocene planktonic foraminifers from Hole 522. 1-4. Globorotalia gemma Jenkins, all from Sample 522-33,CC. (1) Umbilical view, scale bar $=30 \mu \mathrm{m}$. (2) Detail of ultimate chamber of Fig. 1, scale bar $=10 \mu \mathrm{m}$. (3) Side view, scale bar $=30 \mu \mathrm{m}$. (4) Spiral view, scale bar $=30 \mu \mathrm{m}$. 5-7. Globigerina angustiumbilicata Bolli, all from Sample 522-29,CC. (5) Umbilical view, scale bar $=30 \mu \mathrm{m}$. (6) Detail near suture between second and third chambers of final whorl, scale bar $=10 \mu \mathrm{m}$. (7) Umbilical view, scale bar $=30 \mu \mathrm{m}$. 8-10. Globoquadrina globularis Bermudez, all from Sample 522-21,CC. (8) Umbilical view, scale bar $=100 \mu \mathrm{m}$. (9) Umbilical view, scale bar $=100 \mu \mathrm{m}$. (10) Detail of penultimate chamber, scale bar $=10 \mu \mathrm{m}$. Note umbilical tooth. 